NBER WORKING PAPER SERIES

\title{
CROSS-PRODUCT AND CROSS-MARKET ADJUSTMENTS \\ WITHIN MULTIPRODUCT FIRMS: \\ EVIDENCE FROM ANTIDUMPING ACTIONS
}

\author{
Xiaohua Bao \\ Bruce A. Blonigen \\ Zhi Yu \\ Working Paper 29521 \\ http://www.nber.org/papers/w29521 \\ NATIONAL BUREAU OF ECONOMIC RESEARCH \\ 1050 Massachusetts Avenue \\ Cambridge, MA 02138 \\ November 2021
}

The authors thank Treb Allen, Carlo Altomonte, Andrew Bernard, Meredith Crowley, Kyle Handley, Olena Ivus, David Jacks, Justin Pierce, Larry Qiu, John Romalis, Peter Schott, Linke Zhu, and participants at the 4th Annual Conference of China Trade Research Group (CTRG) for helpful comments and discussions. Xiaohua Bao acknowledges support from the Social Science Foundation of China (Grant number: 18ZDA069), the National Natural Science Foundation of China (Grant number: 71673177) and the Shanghai Municipal Education Commission (Grant number: 2019-01-07-00-07-E00031). Zhi Yu acknowledges support from the Public Computing Cloud Platform at Renmin University of China. The views expressed herein are those of the authors and do not necessarily reflect the views of the National Bureau of Economic Research.

At least one co-author has disclosed additional relationships of potential relevance for this research. Further information is available online at http://www.nber.org/papers/w29521.ack

NBER working papers are circulated for discussion and comment purposes. They have not been peer-reviewed or been subject to the review by the NBER Board of Directors that accompanies official NBER publications.

(C) 2021 by Xiaohua Bao, Bruce A. Blonigen, and Zhi Yu. All rights reserved. Short sections of text, not to exceed two paragraphs, may be quoted without explicit permission provided that full credit, including $\odot$ notice, is given to the source. 
Cross-Product and Cross-Market Adjustments Within Multiproduct Firms: Evidence from

Antidumping Actions

Xiaohua Bao, Bruce A. Blonigen, and Zhi Yu

NBER Working Paper No. 29521

November 2021

JEL No. F13,F14,L11,L23

\section{ABSTRACT}

Multiproduct firms are responsible for the vast majority of global trade. A prior literature examines how multiproduct firms respond to trade liberalizations that simultaneously affect all of the firms' products and inputs. In contrast, our study uses Chinese firm-product-level export data to examine how an AD action, a very targeted trade policy against a specific product in a specific export destination, affects a multiproduct firms' price and quantity decisions across its other products and export destinations. We find robust evidence for a new phenomenon we call withinfirm cross-product trade deflection whereby an $\mathrm{AD}$ duty against one of the firm's products in one of its export destinations is associated with reduced prices and increased sales of its other products across all markets. This type of effect depends on increasing costs from joint production within multiproduct firms, something that is often assumed away in many models of the multiproduct firm. We also document for the first time a within-firm chilling effect whereby an AD action in one export destination on a product leads the firm to raise price and lower quantity of the product in other export destinations to lower the risk of AD actions in these other markets.

Xiaohua Bao

College of Business

Shanghai University of Finance and Economics

777 Guoding Road

Shanghai 200433

China

xhbao369@shufe.edu.cn

Bruce A. Blonigen

Department of Economics

1285 University of Oregon

Eugene, OR 97403-1285

and NBER

bruceb@uoregon.edu

\section{Zhi Yu}

School of Business

Renmin University of China

59 Zhong Guan Cun Street

Beijing 100872

China

yuzhi@rmbs.ruc.edu.cn 


\section{Introduction}

Multiproduct firms are responsible for the vast majority of global trade. ${ }^{1}$ Given this important feature of the world economy, the past decade has seen the rise of a literature examining the exporting behavior of multiproduct firms. A common focus of this largely theoretical literature has been the effects of a general trade liberalization on the product mix and scope of multiproduct firms. Eckel and Neary (2010) and Bernard, Redding and Schott (2011) develop two very different general equilibrium models of multiproduct firms and yet both show that trade liberalization leads firms to focus on their "core" products and shed marginally-productive products because of the increased competition from trade liberalization. In contrast, Feenstra and Ma (2008), Qiu and Zhou (2013), and Forslid and Okubo (2019) provide models where multiproduct firms expand their product scope after trade liberalization.

As an industrial organization literature documents, there are a variety of potential cost and demand interdependencies across products within multiproduct firms. ${ }^{2}$ For tractability, models of multiproduct firm behavior can only focus on some of these interdependencies while assuming away others which then translates into differences between models in their prediction of whether trade liberalization leads to reduced or increased product scope within the exporting firm. ${ }^{3}$ This makes empirical work especially important to help inform us about which modeling assumptions best fit the actual operations of multiproduct firms.

There is some limited empirical evidence to date on how multiproduct firms adjust to trade policy changes. Bernard, Redding and Schott (2011) find that U.S. firms experiencing above-median import tariff reductions from the Canadian-U.S. Free Trade Agreement reduce the scope of products they produce than U.S. firms experiencing below-median import tariff reductions. This evidence confirms the theoretical prediction that greater competition leads a firm to focus on its "core" products and shed less-competitive products. Relatedly, Mayer, Melitz, and Ottaviano (2014) find that French exporting firms skew sales toward their best performing products in export destinations where they face

\footnotetext{
${ }^{1}$ Manova and Zhang (2009) document that, multiproduct firms accounted for $77 \%$ of all exporting firms in China in 2005, and their exports accounted for 94\% of the total exports, while Bernard Redding and Schott (2010) report that multiproduct firms accounted for $57.8 \%$ of all US manufacturing export firms in 2000 , and their export sales accounted for $99.6 \%$ of the total. These numbers are $47 \%$ and $80 \%$, respectively, for India during the period of 1989-2003 (Goldberg et al., 2010).

${ }^{2}$ For example, see Bailey and Friedlaender (1982) for a survey of cost interdependencies, primarily from economies of scope, in multiproduct firms. Models of demand interdependencies include Brander and Eaton (1984), Shaked and Sutton (1990), Eaton and Schmidt (1994), and Johnson and Myatt (2003). These models typically focus on possible cannibalization of demand across product lines when products are substitutes for each other and its implications for multiproduct firms' decisions about product offerings to consumers.

${ }^{3}$ Other models of multiproduct firm behavior in an international context include Dhingra (2013), Nocke and Yeaple (2014), Mayer, Melitz and Ottaviano (2014), and Arkolakis, Ganapati, and Muendler (2021).
} 
tougher competition. The evidence is more mixed for less-developed countries. Goldberg et al. (2010) do not find any significant changes to product scope in multiproduct Indian firms in the wake of India's 1991 trade liberalization. Similarly, Iacovone and Javorck (2010) find little change in the product scope of domestic sales by Mexican multiproduct firms after the North-American Free Trade Agreement, though such firms did expand product scope in their exports to the U.S., particularly in the areas where there were significant reductions in U.S. import tariffs.

In summary, empirical evidence on how multiproduct firms adjust to trade policy changes has focused primarily on how trade liberalizations affect participation of multiproduct firms in export markets and the scope of products they produce with mixed results. This may be partly due to the limitations one faces when estimating effects based on a trade liberalization event. Because such a liberalization involves the simultaneous change of tariffs on all products (i.e., all of the firms' outputs and inputs), one can only estimate an overall net effect. It becomes problematic to estimate the direct impact of such a liberalization on particular products in the firm's portfolio unless one can adequately control for the impact of the tariff changes to the other products in the firm's portfolio and to the inputs used to produce the product. Relatedly, such a trade policy event does not allow one to identify the cross-product interdependencies that determine how the firm adjusts to trade policy changes. In other words, one cannot gain direct evidence for the internal margins of adjustment for a multiproduct firm in the face of trade policy changes.

In order to address these limitations and provide new evidence for adjustments that occur within multiproduct firms when responding to trade policy changes, our paper examines the case of antidumping (AD) actions. Antidumping (AD) is one of the most frequently used trade policies in the world. From 1995 to 2020, the World Trade Organization reports there were 6,300 AD investigations in the world - an average of over 250 cases annually. ${ }^{4} \mathrm{AD}$ duties are targeted trade policy actions that lead to import duties on a particular product in a particular country. Because it does not directly impact the multiproduct firm's other products or export destinations, we can use these isolated events to identify whether, and how, a tariff change on one product affects prices and sales of its other products both in the market where the $\mathrm{AD}$ action occurs and in other export destinations.

Theoretically, there are a number of important channels of interdependence in multiproduct firms that may cause an $\mathrm{AD}$ action in one export destination against one product to have potential impacts across the multiproduct firm's other products and export destinations. The first is demand interdependence if the firm's other products have a significant substitute or complementary relationship in downstream use with the targeted product.

\footnotetext{
${ }^{4}$ These data were accessed from the WTO website, https://www.wto.org/english/tratop_e/adp_ e/adp_e.htm on August 10, 2021. Sixty-five countries were responsible for these AD initiations with Australia, Argentina, Brazil, Canada, China, the European Union, India, and the United States each responsible for over 250 initiations.
} 
For example, if two products are (imperfect) substitutes for each other, an AD duty on one of them could divert demand to the other product. The second is cost/productivity interdependence in which a decrease in sales and production in the targeted product has an impact on production and costs for the firm's other products. For example, if two products share common inputs, such as managerial talent or physical machinery, reduction of sales by one product will affect costs of the other product. A third potential source of interdependency is a political economy one documented by others, where an AD action against one of a firm's products may increase the expected probability of an AD action against its other products to the destination taking the AD action or even against any of its products in other destinations. This is related to what the AD literature calls the potential "chilling" effect of AD actions. As we describe next, our empirical analysis can unpack and identify a number of these varying channels of cross-product and cross-market interdependencies in multiproduct firms.

We use firm-product-destination level export data of Chinese firms during the period from 2000 to 2006 to examine how an AD action against one of the firm's products may cause export effects across the firm's products not targeted by the AD action, not only to the export destination that is the source of the $\mathrm{AD}$ action, but to other export destinations for the firm. According to WTO statistics, there were 1,836 AD initiations a year during this paper's sample period from 2000-2006, with China the target of 377 (or 20.5\%) of the total AD investigations.

Our empirical analysis uncovers evidence of a number of within-firm adjustments by multiproduct firms, of which some have never been documented in the literature to our knowledge. Regarding own-product effects, we find that while an AD action on a product in a particular export destination leads the firm to raise the price of that product in that market and decrease its quantity, it also leads the firm to raise the price and lower sales of that same product in other export destinations. The AD literature has long-documented that firms targeted by AD will react by increasing prices and lowering quantities to reduce dumping and hopefully get more favorable treatment on their future exports. Raising prices and lowering quantities of exports of the product to export destinations other than the market where the $\mathrm{AD}$ action takes place is consistent with a more recent $\mathrm{AD}$ literature. Tabakis and Zanardi (2017) document that AD actions against a particular product can "echo" across countries and papers such as Vandenbussche and Zanardi (2010) have argued that $\mathrm{AD}$ actions on one product and import source can have a "chilling" effect on imports of other products or from other country sources. Our analysis is the first to find evidence for a within-firm chilling effect, whereby a firm raises prices and reduces sales of the product across all its export destinations, not just the destination where the AD action occurs. $^{5}$

\footnotetext{
${ }^{5}$ This within-firm chilling effect is seemingly inconsistent with a phenomenon labeled trade deflection by Bown and Crowley (2007). Using Japanese product-level data, they show that exports of a product
} 
Further novel results from our empirical analyses are connected to how an AD action on one product in an export market affects export sales of the firm's other products. Here, we find that an AD action significantly affects prices and export sales of the other products in a multiproduct firm's portfolio in a variety of ways. First, we document a new phenomenon we term within-firm cross-product trade deflection. When one product of a multiproduct firm is targeted by an $\mathrm{AD}$ action, we find the firm lowers prices and increases sales of its other products - both in the country where the AD action takes place and in other export destinations as well. This type of response by the firm is consistent with a model of the firm where there is a joint production function which displays increasing costs. A decline in sales and production of one product leads to lower marginal costs for its other products and the firm therefore optimally increases production and sales of those products. This is some of the first general evidence for this of which we are aware and is a feature of multiproduct firms that is often assumed away in models of multiproduct firms.

Exploring various dimensions of heterogeneity in our data uncovers a number of additional insights into within firm adjustments by multiproduct firms. First, our results are strongest when we eliminate state-owned enterprises and firms that are primarily trade intermediaries, leaving private manufacturing firms. While the result for stateowned enterprises is not surprising, the result for trade intermediaries has an obvious explanation as well - a trading intermediary has many more products over which to spread adjustments, so the average adjustment per product-country combination is smaller.

Second, there are very different responses by multiproduct firms between situations when their core product faces an $\mathrm{AD}$ action and when a non-core product faces an $\mathrm{AD}$ action. When a core product becomes subject to an AD action, the firm substantially raises prices of the core product in the country where the AD action takes place, presumably to reduce dumping and get more favorable AD duties on the product in the future. But the firm hardly alters prices and quantities of the core product in other export destinations in these situations. ${ }^{6}$ Core products also respond little when one of a firm's non-core products become subject to an AD action. On the other hand, AD actions lead to a lot of adjustments for non-core products within the multiproduct firm and these

go up to other export destinations after it becomes subject to an $\mathrm{AD}$ action in one export destination. As they show, such trade deflection can only occur when marginal costs of production at the firm-level are increasing. Decreased sales in one market leads to lower costs of providing the product to other markets. The inconsistency between our study and Bown and Crowley $(2006 ; 2007)$ may be due to their use of product level data (aggregating over many firms) versus our firm-level data. Bown and Crowley's use of product-level data cannot identify within-firm adjustments such as a within-firm chilling effect. There may indeed be within-firm chilling effects for incumbent Japanese firms, but enough new entry is deflected into other markets, the overall product-level effect could indicate trade deflection. The country of study may also make a difference. Our study uses Chinese data, while Bown and Crowley $(2006 ; 2007)$ uses Japanese data, and a follow-up Bown and Crowley (2010) study using Chinese product level data does not find evidence for trade deflection.

${ }^{6}$ While these effects are still statistically significant, their estimated magnitudes are quite small. 
adjustments are completely different depending on whether the AD action targets the firm's core product or a non-core product. When a core product is subject to an AD action, there is a very strong chilling effect on the non-core products. The firm raises prices and lowers quantity of its non-core products across all export destinations, not just where the AD action took place. Note that this a completely different and additional type of within-firm chilling effect than the own-product reaction described above. In contrast, when a non-core product is subject to an $\mathrm{AD}$ action, the firm substantially lowers prices of its other non-core products to divert export sales to these other products and export destinations.

Finally, exploring heterogeneity across the intensive and extensive margins in our data also uncovers important evidence of within-firm adjustments. We find that the within-firm chilling effect operates primarily on the intensive margin, whereas the trade deflection effects are strongest with new entries. With respect to exit, AD actions have little effect on exit probability of the targeted product in the market where the AD action takes place, suggesting that firms stay to "fight" AD actions. But the AD action significantly decreases exit of the firms' other products, especially in other export destinations, which contributes to within-firm cross-product trade deflection.

Beyond the ones already mentioned, our work is also related to a significant literature that has examined product- and firm-level responses to AD actions. Product-level analyses first appeared in the 1990s with important contributions from Staiger and Wolak (1994), Krupp and Pollard (1996), and Prusa (1997 and 2001). These studies documented that $\mathrm{AD}$ actions had significant negative impacts on imports from countries targeted by the $\mathrm{AD}$ action (trade destruction), while they sometimes also had positive impacts on imports from non-target countries (trade diversion). More recent product-level work by Bown and Crowley $(2006 ; 2007)$ document additional trade responses to AD actions by the targeted exporting countries. They find that after a country is targeted by an AD action, its exports to other export (or third) markets may increase (trade deflection), while sales in the domestic market may also rise, reducing the country's imports from foreign countries (trade depression). Unlike Bown and Crowley's analysis, we are able to not only look at these effects with respect to the product targeted by the AD action, but also for any other non-targeted products sold by the targeted multiproduct firms.

Due to the availability of firm level data, a recent AD literature examines the impacts of $\mathrm{AD}$ at the firm level. Most of these firm-level AD studies focus on the impact of $\mathrm{AD}$ actions on firm-level productivity, exits, and market power of firms in the country imposing AD actions. ${ }^{7}$ Only a few of these studies focus on how AD impacts exporting firms in

\footnotetext{
${ }^{7}$ Konings and Vandenbussche $(2005 ; 2008)$ use a panel data of about 4000 EU producers that were involved in $\mathrm{AD}$ protection and find that $\mathrm{AD}$ protection has positive effects on the market power and markups of domestic import-competing firms, except in cases where import deflection after protection is strong. Pierce (2011) examines data on manufacturing plants in the U.S. and finds that while AD duties have a positive impact on traditional value-based revenue productivity of U.S. protected manufactures,
} 
target countries. Chandra and Long(2013) use detailed firm level data and find robust evidence that the US AD duties led to over $12 \%$ (or $5 \%$ ) decrease in labor productivity (or TFP) of target Chinese firms. They also find that firms with higher initial export intensity experienced both a higher decrease in exports (and total sales) and a larger drop in productivity. Their results suggest reduced economies of scale caused by AD as a possible mechanism for the drop in firm productivity. Lu, Tao and Zhang (2013) use Chinese transaction-level export data over the period of 2000-2006 to investigate how Chinese exporters respond to U.S. AD investigations. They find that U.S. AD investigations cause a substantial decrease in the total export volume of Chinese exporting firms at the HS-6 digit product level, and that this trade dampening effect is due to a significant decrease in the number of exporters, yet a modest decrease in the export volume per surviving exporter. They also find that the bulk of the decrease in the number of exporters is the exit of less productive exporters, direct exporters (as opposed to trade intermediaries), and single-product exporters, rather than their multiproduct counterparts. Consistent with these studies, Jabbour et al. (2019) document the exit of a significant number of Chinese exporters to France when their product is targeted by European Union AD actions; however, the more-productive Chinese firms are able to persist as exporters to the French market in the face of the AD remedies. Importantly, our paper is the first to distinguish between targeted and non-targeted products. Because of the focus on non-targeted products at the firm level, we can provide new evidence on the margins of adjustments across products within the multiproduct firm.

There are only a couple of papers that examine AD actions in the context of multiproduct firms, but neither are very close in focus to ours. Lu, Tao and Zhang (2013) compare the difference between the exit probability of single-product firms and that of multiproduct firms to AD actions, but not its implications for adjustments across products within the firm. Vandenbussche and Viegelahn (2018) show how AD duties on one of a multiproduct firm's input leads it to shift production into its products that rely less on that input. In contrast, we examine how an AD action on one of the firm's outputs impacts the reallocation of exports across its other products.

The paper is organized as follows. Section 2 discusses the prior literature on multiproduct firms and AD protection to develop hypotheses for our empirical analysis. Section 3 provides our empirical strategy, while section 4 details the data we use for our analysis. Section 5 reports our empirical results before section 6 concludes.

the quantity-based physical productivity of those firms actually falls. Moreover, AD protection allows low-productivity plants to continue produce protected products, slowing the reallocation of resources from less productive to more productive uses. Finally, Konings and Vandenbussche (2013) use French firm-level data and find that in an environment of globally fragmented supply chains, firms may be damaged by $\mathrm{AD}$ protection if duties increase input costs of firms covered by the protection; While non-exporting firms benefit from protection, domestic sales of export-oriented firms and exports in general are depressed due to protection. 


\section{Hypotheses}

There are a number of ways in which an AD investigation and duties (we call these AD actions) may affect all products produced and sold by the firm across its export destinations. In this section, we describe the various channels by which AD actions may affect both the quantity and the (unit) price of the firms' products to various export destinations.

\subsection{Effects on exports of the product targeted by the AD action}

The effects on the product that is directly targeted by an AD action have been examined before, most notably by Bown and Crowley (2006; 2007). Given that the firm faces an extra import duty (or expected import duty at the start of an AD investigation) into the export destination, theory clearly predicts that the quantity of exports to the destination for that targeted product will decrease. However, the expected impact on price is less clear. If markets are not perfectly competitive and the firm has some degree of market power, they will likely adjust their price in the face of the AD duty. Standard assumptions on demand predict that the firm will lower prices to the market, so that it shares some of the incidence of the tax with consumers. ${ }^{8}$ However, as documented by Blonigen and Park (2004), U.S. AD law and practices incentivize foreign firms facing AD duties to raise their prices to decrease or eliminate dumping because $\mathrm{AD}$ authorities will adjust $\mathrm{AD}$ duties lower as exporting firms raise their prices. Which of these two effects dominates is an empirical question, though Blonigen and Park find that declines in dumping margins (from increased prices) are prevalent in the U.S. data they examine. To the extent that the firms do not lower their price as much as they otherwise would, or even raise price, because of how AD authorities calculate subsequent AD duties, quantities will fall even more than normal.

Bown and Crowley (2007) also document a phenomenon they call "trade deflection". Faced with $\mathrm{AD}$ actions in one export destination, the firm may redirect exports of the targeted product to other destinations (i.e., "non-AD" destinations) by decreasing the price and increasing the quantity of exports in the targeted product to these other destinations. Bown and Crowley show this result theoretically for the case where there are increasing marginal costs in production and products are (imperfect) substitutes in the marketplace, and then provide empirical evidence in favor of this effect for the case of Japanese exports facing U.S. AD actions. There's other commonly-assumed market and production structures where trade deflection would not occur; for example, monopolistic competition and constant marginal costs. And relevant for this paper, Bown and Crow-

\footnotetext{
${ }^{8}$ For example, if the AD duty is $10 \%$, the firm may lower the export price by $5 \%$ so that consumers in the destination market only experience a $5 \%$ price increase after the duty is imposed. For example, see Feenstra (1989).
} 
ley (2010) find little evidence of trade deflection effects when examining Chinese export responses to US and European Union AD actions.

There is also a potential, politically-motivated countervailing force to trade deflection, at least in the other destinations with $\mathrm{AD}$ laws and significant $\mathrm{AD}$ activity. If trade deflection is a significant possibility, governments in other export destinations may be more inclined to apply their own AD actions against the product. Tabakis and Zanardi (2017) provide a model that illustrates this feature, as well as empirical evidence that $\mathrm{AD}$ actions on a product in one market often appear in (or "echo" to) other export destinations for that product. If firms know that echoing can happen, then there may be a "chilling effect" that mitigates, or even reverses, any motivation for a firm to deflect sales by lowering prices to these other destinations. ${ }^{9}$ This is one way in which AD actions can have chilling effects on other trade flows besides the direct impact on the sales and prices of a product to the destination applying the AD action. There is a literature looking at how $\mathrm{AD}$ actions in a country towards some products and countries can generally have a chilling effect on imports of other products and import sources; see, for example, Vandenbussche and Zanardi (2010) and Egger and Nelson (2011). However, these papers do not examine AD chilling effects within the firm as we do in this paper. In our empirical work below, we can examine the possible chilling effect of echoing by examining whether trade deflection is less likely to destinations that have AD laws and actively apply them.

\subsection{Effects on the multiproduct firm's exports of products not targeted by the AD action}

We now turn to possible effects of $\mathrm{AD}$ actions on a firm's exports of its products not targeted by the $\mathrm{AD}$ action, something that can only be examined in the context of a multiproduct firm and which has not been examined previously. There is even more theoretical ambiguity surrounding the possible effects for these non-targeted products than for the targeted product. Within-firm adjustments across products when one faces an $\mathrm{AD}$ action are sensitive to market structure and production technologies analogous to the ambiguity of whether theory predicts trade deflection with a single product as just discussed in the previous section.

First, if there are no demand or production (cost) interdependencies across products within the firm, then a trade action on one product will not elicit any impact on the firms' other products. ${ }^{10}$ Most multiproduct firm models in the trade literature assume independence of costs, particularly marginal costs, across a firm's products, presumably

\footnotetext{
${ }^{9}$ It's also possible that importers in these other destinations demand less of these products for fear their country may apply AD duties to this product. This would lead to both prices and quantities falling in other destinations. Our evidence below does not support this, but we mention it here for completeness.

${ }^{10}$ Since we are looking at very targeted trade actions, we do not need to think about general equilibrium effects on, say, overall market prices and wages for our setting.
} 
for tractability.

However, if there are joint production aspects such that marginal costs are increasing in the joint output of products, then like the trade deflection example for a single product firm, a trade action on one product that decreases its sales can lead the firm to increase its production and sales of its other products to keep (joint) marginal costs lower. This can lead to lowered prices and increased sales of the non-targeted products in both the export market where the AD action takes place, as well as in other export markets. This latter effect is a newly-identified phenomenon that we call within-firm cross-product

\section{trade deflection.}

Having interdependent marginal cost functions in this fashion within a multiproduct firm is likely quite common. As Demski (2008) writes: "the [multiproduct] firm choses to simultaneously produce this set of products, presumably due an advantage ... that is often called an economy of scope ... We should expect some form of synergy among the [products]. And, once this happens, there is no way to separate factor usage, and hence cost, in an unambiguous product-by-product fashion." When one product experiences a change in demand and changes its factor usage of, say, machinery or managers that are used in common across products, then the production, and therefore costs, of these other products are likely affected.

Fixed costs may generate their own interdependencies. Many of the models of multiproduct firms in a global setting specify that a fixed cost must be paid for each destination to which a firm exports. A firm will only export to that destination provided the sum of the profits from the sales of all the products it exports to the destination cover this destination-specific fixed cost. However, if the marginal cost functions are independent, an $\mathrm{AD}$ action against one of the products (lowering its profits) won't affect sales of the other products provided the sum of the profits for the other products continues to cover the destination-specific fixed costs. On the other hand, if the sum of the profits in a destination no longer cover these fixed costs after one of the products is hit with an $\mathrm{AD}$ action, we would see joint exit of all the firms' products to the destination market even in the case of independent marginal cost functions.

Demand interdependencies are another way in which an AD action on one product can lead to changes in prices and sales of the firms' other products. Many multiproduct models in the literature assume that a firm's products are substitutes for each other in consumer demand. ${ }^{11}$ This can lead to internal cannibalization effects whereby each product "steals" demand from the firm's other products and therefore affects the optimal number and range of products a firm produces and sells. ${ }^{12}$ In these models, an AD

\footnotetext{
${ }^{11}$ As noted in footnote 1, early industrial organization models in this literature include Brander and Eaton (1984), Shaked and Sutton (1990), Eaton and Schmidt (1994), and Johnson and Myatt (2003).

${ }^{12}$ Such models in the international trade literature include Ottaviano and Thisse (2011), Feenstra and Ma (2008), Eckel and Neary (2010), and Dhingra (2013). Other multiproduct firm models, including Bernard, Redding, and Schott (2011) and Mayer, Melitz, and Ottaviano (2014), do not display cannibal-
} 
action on one of the products, lowering demand for the product, will reduce the product's cannibalization effect on the other products, leading to greater demand for the firm's other products. This will lead to the prediction that an AD action on one product will lead to increased prices and sales of the firm's other products. This is another way in which within-firm cross-product trade deflection could arise. However, unlike the marginal cost interdependencies discussed above, substitution effects caused by an AD action in an export market would only lead to within-firm cross-product trade deflection in that particular export market, not in other export destinations. This difference will help us identify between these two mechanisms in the empirical work below.

One might question how much substitution in demand there is across a firm's many products in reality. A fabricated metal products firm may have a range of products from nails to hinges to flanges to bolts. It's not clear that these are very substitutable in demand for customers and those that are highly substitutable are likely to be included in any AD action. However, there is another way in which all products for such a multiproduct firm could be seen as substitutes by customers - if multiproduct firms are like "retail shops" as formulated by Bliss (1988). In Bliss's model, retail shops offer a portfolio of products to customers along with a menu of their prices. Customers must choose to access one of many possible retail shops and incur a fixed cost for that access. They come to the retail shop with a fixed amount to spend and then determine how much to spend on each good in the shop. In our example, a downstream importing manufacturing firm decides which fabricated metal manufacturer to develop a commercial relationship for its various fabricated metal product needs. Among many interesting results from this model, a tax on one of the retail shop's products has an impact on the price and quantity sold of the other goods. To keep its portfolio of products attractive for a customer's decision over which retail shop they will use, a tax on one good can cause the firm to lower prices on its other products, which will also increase the amount purchased of these other goods; i.e., within-firm cross-product trade deflection. At the same time, Bliss's retail shop model best explains within-firm cross-product trade deflection for products going to the same market; importers in that country are paying a fixed fee to access the exporter's products. It's less likely to explain within-firm cross-product trade across export destinations, something which seems only explainable by joint production and interdependent marginal costs.

A final possible force for adjustments in the price and quantity sold of other products within a multiproduct firm's portfolio after one of its products is taxed is that the AD action may bring scrutiny to all the firms' products; i.e., it gains a reputation as a firm that dumps its products in export markets. This is probably most likely to happen in the destination where the AD action occur, but it's possible that it happens in other

ization effects because they assume each firm produces a discrete number of products that do not achieve finite mass in the continuum of products offered by all firms (i.e., a monopolistic competition model with an infinite number of firms or brands). An AD action on a particular firm and product in these models will therefore have no impact on prices or sales of other substitute products. 
destinations as well, particularly those with significant AD activity. Relatedly, an AD action may lead a firm to learn that the probability of $\mathrm{AD}$ actions across is portfolio of products is higher in the destination market (and possibly other destinations) than it previously thought. ${ }^{13}$ This is another new phenomenon not previously discussed in the literature to our knowledge that we call a within-firm chilling effect. Everything else equal, this effect should lead the firm to increase price and lower quantity of its non$\mathrm{AD}$-action products to the destination where the AD action has occurred and possibly to other destinations as well.

\subsection{Summary of possible effects}

This section has described a number of possible adjustments that multiproduct firms may make in the face of an $\mathrm{AD}$ action against one of their products in one of their export markets, including two new hypotheses of within-firm cross-product trade deflection and within-firm chilling. Table 1 summarizes the hypotheses, listing the direction of the various effects on price and quantity of the firm's product-level exports.

Panel A of Table 1 summarizes effects for the product that is subject to an AD action for various modeling assumptions, both for the market where it is subject to the AD action and other export markets. For all the scenarios that we (and past literature) generally consider, the price increases and quantity fall in the export market where the product becomes subject to an $\mathrm{AD}$ action. However, the expected effect on the product's price and quantity in other destinations depends on modeling assumptions. Row 1 assumes constant marginal costs in which case an $\mathrm{AD}$ action in one destination has no impact on the product's price or quantity in other destinations; i.e., no trade deflection. Row 2 assumes an increasing marginal cost function, as in Bown and Crowley (2007), and therefore predicts trade deflection results in other markets, where the firm lowers the price in those markets to sell more. In contrast, row 3 assumes no increasing marginal costs but instead a chilling effect of the AD action across markets. Under that assumption, the firm raises prices and lowers quantity of the product across all markets.

Panel B of Table 1 summarizes possible effects under various scenarios for the products of the multiproduct firm that were not targeted by an AD action. Row 1 provides the base scenario, where there are no cost or demand interdependencies between these products and the product targeted by the $\mathrm{AD}$ action. In this case, we would not expect to see any impact on price or quantity of these "other" products in any of the export destinations, including the market where the AD action takes place. Not shown in the table, but briefly discussed above, is the possibility that an AD action on one product of

\footnotetext{
${ }^{13}$ Blonigen (2006) provides evidence that domestic firm petitioners file for $\mathrm{AD}$ actions learn how to increase their chances of a successful AD action through past petitions, but we are not aware of any prior papers that have examined the possibility of learning on the part of firms exporting to markets with $\mathrm{AD}$ activity.
} 
a multiproduct firm could lead it to stop exporting any of its products to that market if there is a common fixed cost for accessing that market. We'll explore this in our empirical work below. The next two rows in panel B provide expected effects when cost and demand interdependencies are present. When there is joint production amongst the firm's products, resulting in a jointly-increasing marginal cost function, then we get within-firm cross-product trade deflection - an AD action on one product leads to price declines and quantity increases for the firm's other products, potentially across all markets. The next row alternatively considers the case where there is no joint production, but instead products are viewed as substitutes by consumers. In this case, an $\mathrm{AD}$ action on one product boosts demand for the other products, allowing them to increase price and quantity. Note that this substitute effect should only lead to changes in the other products in the market where the $\mathrm{AD}$ action occurs. However, if the product targeted by the $\mathrm{AD}$ action deflects sales to destinations other than where the AD action occurs, then this will tend to crowd out the firm's products in the other markets, leading them to lower price and quantity in other markets. The final row of Panel B indicates expected effects if there is within-firm chilling from the AD action. In this case, the firm's products that are not targeted by the $\mathrm{AD}$ action still have a similar reaction as the target product (i.e., increased price and reduced quantity) due to increased concern about further AD actions.

As one can see, there are a multitude of possible within-firm adjustments across all the products and export destinations of a multiproduct firm when one of its products is subject to an $\mathrm{AD}$ action in one export market. While there are certainly more possibilities of which one could conceive, we have highlighted the scenarios that are most consistent with prior literature and evidence. ${ }^{14}$ Interestingly, the various scenarios all provide some degree of differences in expected results from each other. This provides an opportunity to turn to the empirical evidence to identify which modeling assumptions best characterize adjustments within a multiproduct firm facing an AD action.

\section{Empirical Strategy}

We explore the impact of $\mathrm{AD}$ actions from foreign countries on the exports of Chinese multiproduct firms using the following baseline regression specification:

$Y_{\text {fict }}=\alpha_{1} A D \_P r o d \_M k t_{f i c(t-1)}+\alpha_{2} A D \_$Prod_OthMkt $t_{f i c(t-1)}+\alpha_{3} A D \_O t h P r o d_{-} M k t_{f i c(t-1)}+$ $\alpha_{4} A D \_O t h P r o d \_O t h M k t_{f i c(t-1)}+\theta_{f i c}+\gamma_{c t}+\varepsilon_{f i c t}$.

\footnotetext{
${ }^{14}$ For example, products may be complementary in consumption rather than substitutes. However, prior literature nearly always models products as substitutes and the Bliss (1988) "retail shop" model would suggest that all products within a firm's portfolio are seen as substitutes by consumers to some extent.
} 
The dependent variable, $Y_{\text {fict }}$, is the export price, export quantity, or export participation for product $i$ of firm $f$ exported to country $c$ in period $t$. Our four focus regressors will provide estimates of the impact of $\mathrm{AD}$ actions on a particular product for a firm in a particular export country across all its products and export markets. The first AD regressor, $A D_{-} P_{r o d} M k t_{f i c(t-1)}$, is an indicator variable equal to " 1 " if firm $f$ 's product $i$ faces an $\mathrm{AD}$ investigation from country $c$ in period $t-1$. Its coefficient $\alpha_{1}$ captures the direct effect of an $\mathrm{AD}$ action on the price, quantity, or market participation of the product specifically targeted in the export country undertaking the AD action. This is the effect estimated by many prior studies of AD market outcomes. The next regressor, AD_Prod_OthMkt $k_{f i c(t-1)}$, is an indicator variable equal to " 1 " if firm $f$ 's product $i$ faces an $\mathrm{AD}$ investigation from any country other than country $c$ in period $t-1$. Its coefficient $\alpha_{2}$ captures the "third-country effect" of $\mathrm{AD}$ investigations to see if an $\mathrm{AD}$ action in one country affects the sales of the product in other countries. Prior studies of trade deflection (e.g., Bown and Crowley, 2007) have estimated this effect at the product-level, not at the firm-level.

The next two regressors allow us to examine whether there are AD impacts across products within multiproduct firms. AD_OthProd_Mkt $t_{f i c(t-1)}$ is an indicator variable equal to " 1 " if firm $f$ has any product other than $i$ that faces an AD investigation from country $c$ in period $t-1$. Its coefficient $\alpha_{3}$ captures the "other product" effect whereby an $\mathrm{AD}$ action against one of a firm's product in an export market impacts the exports of its other products to that same market. The final focus regressor, AD_OthProd_OthMkt $t_{f i c(t-1)}$ is an indicator variable equal to " 1 " if firm $f$ has any product other than $i$ that faces an AD investigation from any country other than $c$ in period $t-1$. Its coefficient $\alpha_{4}$ captures a "other product - other country" effect whereby an AD action against the firm on another one of its products in another market affects the firm's sales of product $i$ in country $c$. Coefficients $\alpha_{3}$ and $\alpha_{4}$ have not been estimated in the literature to our knowledge and will give us new insights into cross-product adjustments within multiproduct firms.

As controls, we rely on a set of rigorous fixed effects. First, we include firm-product(destination) country $\left(\theta_{\text {fic }}\right)$ fixed effects, which control for not only firm-level productivity, but also firm-product productivity effects and the firm's capabilities in exporting product $i$ to country $c$. The effects of any time-invariant regulation or tariffs faced by product $i$ by firm $f$ in country $c$ will also be subsumed into these fixed effects. Second, there are country-level factors such as GDP and exchange rates that can significantly impact demand for the firm's products and which we control for with (destination) country-year fixed effects $\left(\gamma_{c t}\right)$. We do not include product-year fixed effects since such a fixed effect would confound our estimate of the cross-country changes that may occur for a product that is targeted by an $\mathrm{AD}$ action. ${ }^{15}$ Likewise, we do not include firm-year fixed effects

\footnotetext{
${ }^{15}$ For example, suppose that an $\mathrm{AD}$ action on a product in one market in a given year leads to a
} 
because it would confound our ability to estimate any systematic changes across products that may occur in the firm in the wake of an $\mathrm{AD}$ action. $\varepsilon_{\text {fict }}$ represents a mean-zero error term and we note that we weight observations by their export value.

Identification of our estimates depends on the lag structure of equation 1, as we are estimating the impact of an AD action on the firm's pricing and sales the year after the $\mathrm{AD}$ action occurs. There is some degree of measurement error because we have annual data and the $\mathrm{AD}$ action could occur at any point during the year. The earlier an $\mathrm{AD}$ action occurs in the prior year, the more the prior year's outcomes (price, quantity and participation) could be affected by the $\mathrm{AD}$ action, making our estimates less precise. This data issue would argue that our estimates are a lower bound on the impacts of AD actions. $^{16}$

\section{Data}

\subsection{Trade Data}

The trade data that we use in the empirical analysis is the Chinese transaction-level trade data in the period from 2000 to 2006. This dataset was collected by China's General Administration of Customs (CGAC). The dataset contains rich information for all Chinese export and import transactions. For each export or import transaction, the data records the Chinese firm (and its ownership), product (at HS8 level), country (destination of exports or source of imports), time (year and month), value, quantity, custom, transportation mode, trade type (ordinary trade or processing trade), etc. We only use the export data in our analysis, since we would like to explore how AD actions initiated by foreign countries against China impacts exports of Chinese firms.

We remove export transactions with missing information on firm, product, country, time or value, and then aggregate the data to firm-country(destination)-product(HS6)year level. We aggregate the products from the HS8 level to the HS6 level, since we need to combine Chinese exports data and foreign AD data by product, and HS codes are only consistent at 6-digit level across countries. We only keep multiproduct firms (firms that export at least two HS6 products in a year) for our analysis below.

Panel A of table 2 reports number of firms, number of multiproduct (MP) firms, share of multiproduct firms, total export value, exports by multiproduct firms, and share of exports by multiproduct firms for each year during the data-coverage period. During the period, the total number of exporting firms increased from 62,536 to 158,928 , the number

chilling effect on future sales of the product across all the export markets. This chilling effect would get subsumed into a product-year fixed effect and not our focus AD regressors.

${ }^{16}$ This is also the reason why we have our specification in levels of the variables, rather than changes. If the variables were specified in changes, one would need to be confident that one is identifying the precise time period that the $\mathrm{AD}$ action occurs and causes the one-time changes. 
of multiproduct firms increased from 44,931 to 124,278, and the share of multiproduct firms increased steadily from $71.8 \%$ to $78.2 \%$; the export value of all firms increased from 248 to 958 billion dollars, the export value of multiproduct firms increased from 230 to 901 billion dollars, and the share of export value by multiproduct firms was fairly stable at 92.7-94.1\% during the whole period. Thus, multiproduct firms dominate Chinese exports in terms of both the share of firms and the export value.

For the sample of multiproduct firms, which are the objective of our research, we report in Panel B of Table 2 the average number of destination countries/products(HS6) and country-product pairs per firm in each year. In Panel $\mathrm{C}$, we report the share (in terms of number of firms and export values) of manufacturing firms (as opposed to trade intermediaries ${ }^{17}$ ), non-State-Owned Enterprises (non-SOEs), and manufacturing non-SOEs in each year since we will explore below whether impacts of $\mathrm{AD}$ on multiproduct firms differ across different types of firms. As we can see, the average number of destination countries and exported products per firm were stable over time at 7-8 and 19-21, respectively. The average number of destination country-product pairs per firm steadily increases from 36 to 41 . The share of manufacturing firms decreased steadily from $85.1 \%$ to $73.6 \%$ in terms of number of firms, but increased steadily from $64.6 \%$ to $77.9 \%$ in terms of export value. The share of non-SOEs increased steadily in terms of both number of firms and export value, from $81 \%$ to $93.2 \%$ and from $53.9 \%$ to $79.6 \%$, respectively. The share of manufacturing non-SOEs decreased from $76.2 \%$ to $69.8 \%$ in terms of number of firms, but increased steadily from $50.6 \%$ to $68.2 \%$ in terms of export value. These trends are due to the fact that China lifted the regulations on firms' trading rights after its entry of WTO in 2001, which led to the rapid growth of trade intermediaries and non-SOEs involved in international trade. However, the share of export value by trade intermediaries decreased over time.

\subsection{AD Data}

$\mathrm{AD}$ actions begin with an investigation to determine whether a firm is exporting a product to the investigating country at a price that is unfairly low (typically defined as what it sells the product in its own country) and is causing injury to the competing domestic industry. ${ }^{18}$ Investigations typically take from 6 months to a year to be completed. If unfairly low prices (i.e., dumping) and injury to the domestic industry are found, then the country may apply a remedy according to WTO rules. The AD measure used to

\footnotetext{
${ }^{17}$ We use the method in Ahn, Khandelwal and Wei (2011) to identify whether an exporting firm is a trade intermediary or a manufacturing exporting firm by looking at firm names. If a firm name contains Chinese characters such as "export", "import", "export and import", "commercial", "trade", etc., then it is classified as a trade intermediary; otherwise it is classified as a manufacturing exporting firm.

${ }^{18}$ The World Trade Organization has established these two criteria - unfairly low price and injury to the domestic industry - as necessary for a country to impose a form of import relief. For further information on $\mathrm{AD}$ trade protection beyond what we describe here, see https://www.wto.org/english/tratop_e/ adp_e/adp_e.htm and Prusa (2001)
} 
counteract dumping can vary, though often the countries choose to apply an AD duty that is equal to the amount by which the price is below a fair price, which could be in the form of an ad valorem or specific import duty on the product. Other possible AD measures are agreements by the exporting firm to raise its prices to an agreed-upon price floor, often called a price undertaking.

We use the World Bank's Global AD Database as our data source for our AD action variables. ${ }^{19}$ The Global AD Database contains information for AD cases for the primary AD-using countries across the world since the 1980s. For each case, the data records the initiating country, target country (countries), target product (products, from HS4 to HS12 level), initiating and decision dates, decision type, and AD measure imposed.

We define our $\mathrm{AD}$ indicator variables as taking the value of " 1 " in the year the AD case is initiated. We do this because prior literature (e.g., Staiger and Wolak, 1994) finds that there can be significant changes in firm behavior as soon as an AD investigation is initiated because countries begin closely monitoring the firm's behavior and sometimes assessing preliminary penalties. Because of this and the length of AD cases (about a year long), specifying our AD indicator variables as taking the value of " 1 " only after an AD measure comes into place can lead to underestimates of the AD effect because there has already been a prior period (between initiation and AD measure) where the firm may have already changed its behavior. The majority of AD initiations leads to AD measures, which is certainly true in the case of China over our sample years. As we will report below, our results are qualitatively identical if we specify our AD indicator variables as taking the value of " 1 " for $\mathrm{AD}$ cases that lead to a trade remedy, such as an AD duty, or does not. ${ }^{20}$

Given that our Chinese trade data is for the period of 2000-2006, but our AD regressors are lagged one year, we use data on $\mathrm{AD}$ initiations against China for the period 1999 to 2006, which are specified at the initiating country-product-year level. Panel A of Table 3 reports the number of AD cases initiated by different countries in each year during the period from 1999 to 2006. During this period, 20 countries in the world initiated a total of 380 AD investigations against China, and 291 (77\%) of these cases had some kind of final AD measure imposed.

\subsection{Combined Data}

We merge the initiating country-product-year level AD data to the firm-country(destination)product(HS6)-year level Chinese export data. Note that the products in the AD data

\footnotetext{
${ }^{19}$ Construction of the database was led by Chad Bown (see Bown (2011) for more details) and is available at https://elibrary.worldbank.org/doi/abs/10.1596/1813-9450-3737.

${ }^{20} \mathrm{~A}$ related issue is the concern that a case that is initiated at the very end of a year is one that will mainly be adjudicated the following year (AD cases typically last from 6-12 months). Because of this, we code $\mathrm{AD}$ cases that are initiated in the first six months of the year as belonging to that year, but code $\mathrm{AD}$ cases that are initiated in the last six months of the year as belonging to the subsequent year.
} 
range from HS4 to HS12 level, and HS codes are only consistent across countries at the 6-digit level. Thus for target products at the HS4 level in the AD data, we merge them to the Chinese export data at the HS4 level, but for target products at the HS6 level or at a more disaggregate level (HS8, HS10, HS12, etc.) in the AD data, we merge all of the relevant codes to the Chinese export data at the HS6 level. Hence, in the combined data, when we say an HS6 product is a "target" in an AD case, it means either all sub-products within that HS6 category are targeted, or only some of the products within that HS6 category are actually targeted by an AD action. This measurement issue means that our estimates may understate the full impact of these AD actions.

Panel $\mathrm{B}$ of Table 3 reports the exports impacted by AD cases. The number of country-product pairs targeted by AD initiation cases varies from 60 (2003) to 1335 (2006), which accounts for $0.029 \%$ (2003) to $0.054 \%$ (2006) of all exported country-product pairs. Export value impacted by AD cases varies from 0.80 (2000) to 4.12 (2006) billion dollars, which accounts for $0.32 \%$ (2000) to $0.69 \%$ (2002) of Chinese total export value in each year.

Since our AD data are at the HS6 level, we also collapse our export data from HS8 level to HS6 level. However, the quantities and prices of different HS8 products within a same HS6 category might not be comparable with each other because they are measured in different units. Hence, we use the following procedure to construct a "normed" quantity and price for each HS6 castegory. First, we construct the firm-HS8-country-year level export value and quantity (simply aggregated from the transaction level), which also allows construction of the price as export value divided by quantity. Second, we next calculate the mean price/quantity of each firm-HS8-country cell across different years in the sample period. Third, we divide the firm-HS8-country-year level price/quantity (from the first step above) by their firm-HS8-country level averages (from the second step above) to get a "normed" firm-HS8-country-year price/quantity. Fourth, we take the weighted average of the "normed" firm-HS8-country-year quantity/price for all HS8 products within the same HS6 (using the value share of each HS8 within HS6 as the weight) to get the "normed" firm-HS6-country-year level quantity/price, which are the dependent variables for our regressions.

\section{Results}

\subsection{Base Results}

Table 4 provides base results when we use equation (1) to estimate the price and quantity changes by a multiproduct firm in the face of an AD action on a product in an export destination. Our set of observations consists of all firm-product-country combinations with positive export values over the sample period, yielding close to 4.5 million observa- 
tions. The regressions include a full set of firm-product-country (fic) and country-time (ct) fixed effects and yields an $R^{2}$ statistic of nearly 0.49 for the price regression and 0.27 for the quantity regression.

Turning to the first row of coefficient estimates in Table 4, the coefficient on the $A D \_P r o d \_M k t$ indicator variable in the price regression is positive and statistically significant, while the coefficient in the quantity regression is negative and statistically significant. This indicates that the direct effect on the product targeted by the AD action in the export destination applying the $\mathrm{AD}$ action is for the firm to increase price and reduce quantity in that market, and it is consistent with prior evidence in the literature about the effects of $\mathrm{AD}$ actions on exporting firms. While the tax incidence literature would suggest that a firm will reduce price when its product faces a standard import tax, AD actions do not lead to standard import taxes. They either lead to agreements by the exporting firm to raise itsa price to avoid import taxes or an $\mathrm{AD}$ duty that can only go away in the future if the firm increases its price. In short, AD remedies are constructed to induce the firm to raise its price and, hence, stop dumping, in order to avoid large penalties. Given our dependent variables are in log form and our coefficients are small in value, the coefficient on all our indicator-variable regressors can be read as approximately the percentage change in the dependent variable (in decimal form). ${ }^{21}$ Thus, the AD_Prod_Mkt coefficients indicate that an AD action on a product leads the firm to raise (on average) the price of that product by approximately $3.9 \%$ in that export destination, which is associated with a $5.3 \%$ decline in quantity.

The next row of coefficients in Table 4 provides estimated price and quantity impacts for a multiproduct firm beyond the product and export destination where the AD action occurs. The coefficients on the AD_Prod_OthMkt show the estimated price and quantity impacts for the product targeted by the $\mathrm{AD}$ action in export destinations other than where the AD action occurs. As discussed above, the literature on trade deflection would suggest that the firm would lower price and raise quantity for the product in the other export destinations, provided marginal costs are increasing. In contrast, the literature on the possible echoing and chilling effects of $\mathrm{AD}$ actions would suggest that an $\mathrm{AD}$ action in one market will lead the firm to have concerns about trade policy actions on the same product in other markets, therefore incentivizing the firm to raise prices and lower quantity in those markets as well. The coefficient estimates indicate that the chilling effect dominates with a positive and statistically significant coefficient on the price and a negative and statistically significant coefficient on quantity. As one would expect, the price coefficient is about half the size (around a $2 \%$ increase) of the price increase that we see for the product in the market where the AD action occurs. By this metric, the chilling effect in other markets is about half of the direct effect on the product in the

\footnotetext{
${ }^{21}$ The exact formula to convert the coefficient into the percentage change in the dependent variable (in decimal form) is the exponent of the coefficient minus one.
} 
market where the $\mathrm{AD}$ action takes place. Interestingly, the chilling impact on quantity for the product in other export markets is equally as large (5.3\%) as in the market where the $\mathrm{AD}$ action takes place. This turns out to not be surprising when we consider the adjustments taking place by the firm with its other products. As we discuss below, the firm reacts to an $\mathrm{AD}$ action on one product by reducing its price and increasing quantity on the exports of its other products. Thus, while the firm only increases the price by $2 \%$ on the $\mathrm{AD}$ product in other export markets, its sales falls much more because the firm simultaneously lowers prices on its other products and they steal sales away from the AD product. This requires that these products are (imperfect) substitutes in consumption.

Before moving to the other results, we also note that there is a plausible reconciliation between our results and prior studies finding evidence that firms deflect their exports of a product to other markets when it is subject to an $\mathrm{AD}$ action in one of its export markets. First, unlike what they found for Japan in their 2007 study, Bown and Crowley (2010) finds little evidence for trade deflection for the case of Chinese products subject to $\mathrm{AD}$ actions. In addition, these prior Bown and Crowley studies were analyses at the product level, not the firm-product level we examine. Why might this matter? While our results suggest that the firms subject to $\mathrm{AD}$ action may not deflect (or even the opposite because of chilling effects), it may incentivize other firms to newly enter the other export markets with this product.

Coefficients on AD_OthProd_Mkt and AD_OthProd_OthMkt, the final two regressors in Table 4, provide evidence of how the firm adjusts prices and quantities for products other than the product targeted by an AD action. The evidence here is clearly toward deflection of sales to products other than the product targeted by the AD action. The coefficient for both regressors in the price regression are negative and statistically significant, whereas they are positive and statistically significant for both in the quantity regression. The firm lowers prices to increase quantity sold on its other products in both the market where the AD action takes place (coefficients on $A D_{-}$OthProd_Mkt) and in other markets (coefficients on AD_OthProd_OthMkt). Both of these effects are the phenomenon we label "within-firm cross-product deflection." As our hypothesis section discusses above, the coefficient pattern for within-firm cross-product deflection in the market where the AD action occurs is consistent with either Bliss's retail shop model or the existence of joint production interdependencies that involve jointly increasing marginal costs. However, the evidence for within-firm cross-product deflection in markets other than where the AD action is only consistent with joint production interdependencies. Thus, our evidence is most strongly consistent with the hypothesis of joint production interdependencies. Note that demand interdependencies are not consistent with the sign patterns we see for these two regressors. If products were substitutes, then an increased price for the targeted product should increase demand for the other products, leading them to have both a higher price and higher quantity. And it would be just the opposite if they were complementary 
goods in demand - lower prices and lower quantities.

Turning to the magnitude of the effects for these final two regressors, our estimates for $A D_{-}$OthProd_Mkt indicate that the firm lowers its price by about $2.7 \%$ and sees an increase in quantity sold by about $1.3 \%$ for products other than the one targeted by the AD action. These are modest effects, but notable because the firm may be especially concerned about lowering price in a market where one of its products was targeted for a dumping investigation; i.e., there could be some cross-product chilling effect. As we would expect, this cross-product chilling effect should be less in markets other than where the $\mathrm{AD}$ action takes place, allowing the within-firm cross-product deflection effect to be even larger. And that is what we find with our coefficient estimate on the regressor, AD_OthProd_OthMkt, where the within-firm cross-product deflection effect leads to a $3.7 \%$ decrease in prices for other products sold by the firm in other markets and a resulting increase in quantity of $4.7 \%$.

In summary, our base results provide strong evidence for within-firm cross-product deflection when one of a multiproduct firm's products is subject to an AD action in one of its export markets. This is a newly-documented phenomenon that provides evidence of a certain type of production (and marginal cost) interdependency within multiproduct firms; namely, shared inputs and/or joint production that means increasing costs for the joint production of the firm's products. We also find substantial evidence for the chilling effect of AD actions across other markets for the product that is subject to the AD action, but less evidence for such chilling effects across products. Evidence on chilling effects within a firm is also novel in the literature to our knowledge as well.

\subsection{Heterogeneity in Adjustments Across Firm Types}

There are a number of different types of firms that we can differentiate in our sample and one may expect that they may differ in how they make within-firm adjustments in the face of AD actions. Table 5 provides coefficient estimates separately for price and quantity regressions for various types of firms in our sample. The first two columns provide our base results when we run the full sample for sake of comparison. The first comparison we consider is between state-owned enterprises (SOEs) and private firms (non-SOEs). Firm adjustments by SOEs may be quite different from private firms to the extent that internal resource prices (and even effective domestic output prices they face) may be distorted by state subsidization and other policies. SOEs can also be treated differently in AD actions for these reasons, which may change how they respond to these trade policies. Columns 3 through 6 of Table 5 provide our results when we split the sample into observations connected to SOEs, which comprise $44 \%$ of the observations in our sample, and nonSOEs. The estimated coefficients for the non-SOEs are qualitatively identical to the base results for both the price and quantity regressions, though the magnitude of the 
coefficients are consistently and significantly greater - anywhere from about $10 \%$ greater to more than double. Relatedly, the estimated coefficients for the SOEs suggest much smaller responses to $\mathrm{AD}$ actions, though the sign pattern is again generally consistent with the base results. Therefore, pooling these different firm types does not likely affect the sign patterns we find for how firms make adjustments in response to AD actions, but does lead to an underestimate of how large they are for private, independent firms.

Another distinction in firm types that we can identify in our data is that between firms who are primarily trade intermediaries and those that are primarily manufacturing firms. The main difference between these two types of firms is that trade intermediaries will generally have many more products and export destinations over which to make adjustments. The average number of HS6 products and HS6 product-country pairs within a firm-year are 55 and 106, respectively, for trade intermediaries, which is 4-5 times larger than those for manufacturing firms (11 and 24, respectively). Since a trade intermediary can spread adjustments across many more products and product-country combinations, we would expect that the average adjustment on each margin should be smaller for trade intermediaries than for the manufacturing firms. And this is exactly what we find in our estimates seen in columns 7-10 of Table 5. The manufacturing firms have the exact same sign pattern as the base results, but the coefficients are generally about $50 \%$ larger. In contrast, the coefficients for the regressions with the sample of trade intermediaries are substantially lower in magnitude (half or less) than the base results despite generally having the same sign pattern. ${ }^{22}$

The final columns of Table 5 provide estimates when combining these two dimensions of heterogeneity and only sampling non-SOE, manufacturing firms (Columns 11-12). Such firms comprise about $43 \%$ of our total sample. Our coefficient estimates for this subsample provide sign patterns that are identical to our base results using the full sample, but are also significantly larger in magnitude than our base results. Because most theories of the firm are related to these types of firms that produce the products they sell and are free of direct control by government, we focus on this subsample for the remainder of our reported results. However, we note that the sign patterns of the coefficients for our AD regressors are nearly qualitatively identical in all our results regardless of whether we sample all firms or only the non-SOE, manufacturing firms.

\footnotetext{
${ }^{22}$ Nearly all of the observations in our sample involve multiproduct firms with less than $3 \%$ of the observations involving single product firms. We can only estimate coefficients for our first two AD regressors for single product firms because they do not sell other products, and our regression estimates suggest a small and significant increase in price of $1.2 \%$ for the product targeted by $\mathrm{AD}$ in the market where the $\mathrm{AD}$ action takes place, but small and insignificant coefficient estimates for the other $\mathrm{AD}$ regressor. In other words, there is little sign of trade deflection or a chilling effect on the single-product firm's sales in other markets after the product becomes subject to an AD action in one of its export markets.
} 


\subsection{AD Definition and Use}

In our analyses to this point, we have defined $\mathrm{AD}$ actions as any initiation of an $\mathrm{AD}$ investigation. However, outcomes of AD initiations are varied. First, some AD investigations find no evidence for dumping and/or injury to the domestic industry and, therefore, no trade remedies are applied. We might expect that firm responses to these "negative" AD investigations may be more muted or even insignificant. Alternatively, past AD literature has found that the initiation of an AD case, even if the ultimate ruling is negative, leads to substantial impacts on import prices and quantities of the products subject to the AD investigation (see, e.g., Staiger and Wolak, 1994). In columns 3 and 4 of Table 6 , we show our results for price and quantity responses when we define our AD indicator variables as taking the value of "1" only when an initiated AD case results in an affirmative decision; AD initiations that lead to negative determinations are coded "0" along with other observations where there is no AD initiations. Columns 1 and 2 provide our estimates for the base case where the the $\mathrm{AD}$ variables indicate the initiation of any $\mathrm{AD}$ case regardless of outcome. Sign patterns of the coefficient estimates are identical across these two specifications. However, the magnitude of the price and quantity responses by firms for the product subject to the AD action are unexpectedly smaller when we eliminate the negative AD cases, not larger, and the coefficient on quantity is statistically insignificant. One possible explanation for this is that firms may provide little response when they become subject to a very large AD duty in affirmative cases; i.e., firms may "give up" and take what sales and profits they can make if they stay in the market.

To explore this, we next eliminate observations related to $\mathrm{AD}$ duties over $50 \%$, and columns 5 and 6 in Table 6 provide these estimates. Once we eliminate these very large AD duty cases from our sample, the estimates suggest that firms facing more reasonable $\mathrm{AD}$ duties (below 50\%) raise prices over $8 \%$ in the market where the $\mathrm{AD}$ action takes place, with over a $20 \%$ decline in quantity. We also see a larger increase in price and larger decrease in quantity for the $\mathrm{AD}$-investigated product in other markets than when we include observations with very large AD duties. The responses by the firms' "other" products are not generally that different whether we exclude very large AD orders or not.

Another important distinction for our analysis is that some countries do not have $\mathrm{AD}$ laws and, therefore, cannot apply their own AD remedies. This may affect where exporting firms divert their product if targeted with an $\mathrm{AD}$ action in one of their export markets and, in particular, the chilling effect hypothesis; i.e., firms may not worry about dumping into countries without $\mathrm{AD}$ laws versus those with $\mathrm{AD}$ laws. In columns 7-8 and 9-10 of Table 6, we provide estimates for a subsample of export destinations with AD laws and the subsample without AD laws, respectively. As one can see, the coefficient pattern of our $\mathrm{AD}$ variables for exports to countries with $\mathrm{AD}$ laws in columns 7 and 8 is identical to our full-sample results in columns 1 and 2 with very similar magnitudes. 
Our estimates for the sample of countries without AD laws (Columns 9 and 10 of Table 6) are substantially different. First, note that we cannot estimate coefficients for the $\mathrm{AD}$ impact of any products in the countries where the $\mathrm{AD}$ action takes place because we are using a sample of countries without $\mathrm{AD}$ laws; i.e., we cannot estimate the coefficients on AD_Prod_Mkt and AD_OthProd_Mkt with this sample of non-AD countries. Turning to the other two coefficients, the coefficient on the AD_Prod_OthMkt variable in the price regression across the two samples (countries with $\mathrm{AD}$ law versus countries without $\mathrm{AD}$ law) is consistent with the chilling effect hypothesis. When a product is subject to an AD action, the firm raises the price in other export markets with AD laws to avoid further AD actions (column 7 coefficient), while it will lower the price of the product in other export markets without AD laws (column 9 coefficient). However, the coefficient on the AD_Prod_OthMkt variable in the quantity regression is a bit surprising. Despite the price drop in non-AD markets, the coefficient on AD_Prod_OthMkt suggests that quantity falls a lot, and this drop is much larger than what we see for the AD product in other markets that have AD laws where the firm raises prices. A plausible explanation for this is that when a product is targeted by an $\mathrm{AD}$ action in any market in the world, firms across all countries divert their exports of this product to countries without AD laws, stiffening competition considerably. Thus, Chinese firms experience quantity losses in these non$\mathrm{AD}$ markets even though they are also lowering prices. Interestingly, this explanation suggests that an $\mathrm{AD}$ action in one country with $\mathrm{AD}$ laws can have a chilling effect for all countries with $\mathrm{AD}$ laws, and then create large deflection to countries without $\mathrm{AD}$ laws. There is much less difference in responses to AD actions for the other products of multiproduct firms in markets other than where the AD action occurs; i.e., the coefficient on AD_OthProd_OthMkt for both the price and quantity regressions are similar across the two samples. For both the sample of countries with AD laws and the sample of countries without AD laws, multiproduct firms lower the price on their other products in the other markets. The quantity response is once again greater in the non-AD law sample.

We have explored the robustness of these results in a number of additional ways and find that these differences between countries with AD activity and those without are highly robust. First, instead of focusing on whether countries have AD laws or not, we split the sample by countries that use AD policies a lot and those that rarely do. When we do this, we get qualitatively identical results. Second, one may be concerned that these differences are being driven by other country-level factors that are correlated with whether a country enacts $\mathrm{AD}$ laws or not. ${ }^{23}$ However, our results are qualitatively unchanged when we include GDP interactions with our focus variables or only look at top export destinations for Chinese firms. A final concern is that the largest export market without AD laws is Hong Kong, which functions as an entrepot market for China. However, we get nearly identical coefficient estimates if we exclude Hong Kong from our

\footnotetext{
${ }^{23}$ Many countries that do not have AD laws are smaller and/or poorer.
} 
sample of countries without AD laws.

\subsection{Core Versus Non-Core Products}

A significant recent literature on multiproduct firms in the global context have focused on how trade policies affect the firm's core products that are responsible for the majority of its sales. ${ }^{24}$ To explore this issue in our context, we next look at whether within-firm adjustments to AD actions differ depending on whether the AD action targets a firm's core product (its top seller) or one of its non-core products. To simplify our analysis, we define the core as only the top product (across all markets) for the multiproduct firm, defining any other products the firm sell as "non-core". We then explore the effects of AD actions in four possible cases: A) Effects on non-core products when a non-core product is subject to an $\mathrm{AD}$ action, $\mathrm{B}$ ) effects on the core product when it is targeted by an $\mathrm{AD}$ action, C) effects on non-core products when a core product is subject to an AD action, and $\mathrm{D}$ ) effects on the core product when a non-core product is subject to an AD action. Of the firm-product-country-year observations where an $\mathrm{AD}$ action is in place in our sample, $12 \%$ of these involve core products and $33 \%$ of the affected export value, whereas the rest involve non-core products.

Table 7 provides our results for each of these cases in turn. The first two columns of the table provide price and quantity responses in our base case for non-SOE, manufacturing firms for the sake of comparison. The next two columns provide price and quantity responses by non-core products when one of the non-core products is subject to an $\mathrm{AD}$ action (Case A). In other words, we sample only non-core products in our sample and define the $\mathrm{AD}$ variables only with respect to $\mathrm{AD}$ actions against non-core products. The sign pattern is generally identical to the base results for this case, however the magnitudes differ some in interesting ways. Firms hardly alter their pricing and quantity for their non-core product in the destination where the product becomes subject to an AD action. This contrasts with the evidence that firms substantially raise price and lower quantity in the export destination where the $\mathrm{AD}$ action takes place when it involves a core product (as we'll discuss next). However, the adjustments by the firm in other dimensions when a non-core product is targeted by an $\mathrm{AD}$ action are actually much greater than the base case. First, the chilling effect response is higher for the AD-targeted product in the other export destinations (compare coefficients on AD_Prod_OthMkt in columns 3 and 4 to those in columns 1 and 2). Second, the within-firm cross-product trade deflection effect is also stronger when an AD action targets a non-core product (compare coefficients on the AD_OthProd_Mkt and AD_OthProd_OthMkt across case A and the base case). In short,

\footnotetext{
${ }^{24}$ As mentioned in the introduction, Bernard, Redding and Schott (2011) find that U.S. trade liberalization led firms to shed non-core products and focus more on their core products because of increased competition due to the trade liberalization, whereas Goldberg et al. (2010) and Iacovone and Javorck (2010) find little evidence for such effects in the case of India and Mexico, respectively.
} 
the firm does not respond much to an $\mathrm{AD}$ action on a non-core product in the market where the $\mathrm{AD}$ action takes place, but then takes actions to significantly increase sales of its other non-core products across all destinations, while at the same time increasing its price of the targeted product in other destinations to avoid AD actions in those markets.

Columns 5 and 6 of Table 7 isolate the price and quantity responses by the core product when it is targeted by an $\mathrm{AD}$ action (Case $\mathrm{B}$ ); i.e., we sample only the core products in our sample and define the $\mathrm{AD}$ variables only with respect to the actions against core products. There are no coefficient estimates for the last two AD regressors because there are no products "other" than the AD product when we limit the sample to only the core product of the multiproduct firm. The estimates show that multiproduct firms raise prices more for their core product in the market where the $\mathrm{AD}$ action occurs than they do for non-core products. This is consistent with prior literature that firms can successfully lower (or eliminate) AD remedies if they increase prices and lower sales of the targeted product. But, interestingly, the chilling effect for the product in other markets is not as strong for core products as it is for non-core products. In fact, multiproduct firms slightly lower the price of the core product in its other AD destinations (trade deflection), whereas our base results suggest that the average response by firms across all products that get targeted by an $\mathrm{AD}$ action is to raise prices for the product in other destinations (chilling effect).

Columns 7 and 8 of Table 7 provides estimates when we sample only the non-core products and examine their response when an AD action happens to the firm's core product. There are no estimates for the first two AD regressors because we define our $\mathrm{AD}$ variable only with respect to $\mathrm{AD}$ actions against core products and there are no core products in our sample. These estimates are somewhat surprising, as the chilling effect on non-core products is apparently very strong when a core product is subject to an AD action, with the firm raising the price (and seeing decline in quantities) on these products across all markets. Finally, columns 9 and 10 of Table 7 provides estimates when we sample only the core products and examine their response when an AD action happens to one of the firm's non-core products. Here, we see fairly muted and small responses by the multiproduct firms, as one might expect. Actions against one of the firm's more marginal products shouldn't have much impact on its core product.

In summary, our results suggest that multiproduct firms generally respond in much stronger ways when its core product is targeted by an $\mathrm{AD}$ action. It raises the price more in the market where the AD action occurs when its core product is targeted than when one of its non-core products is targeted. In addition, an AD action against its core product leads the firm to raise prices on its non-core products across all markets, presumably to protect them from AD actions, whereas it lowers prices and deflects sales to other markets when one of its non-core products is targeted by an $\mathrm{AD}$ action. 


\subsection{Extensive Versus Intensive Margin}

Adjustments by multiproduct firms to trade policy actions can include both exit and entry of certain products and/or export destinations - the extensive margin. Our estimates to this point have included both intensive and extensive margin changes because we have sampled all observations of export sales by Chinese firms regardless of whether they end at some point in our sample or begin at some point in our sample. Table 8 provides results when we decompose the intensive and extensive (both exit and entry) responses of price and quantity to AD actions. For the sake of comparison, we focus on quantity regressions across all our specifications in Table 8 since price changes are undefined for entry and exit. ${ }^{25}$

Column 1 of Table 8 provides our base case estimate on quantity responses for comparison purposes. We then isolate the intensive margin using a sample where we eliminate any firm-product-country combinations from the sample if they have any year of zero sales during our sample years, which reduces our sample down to less than 400,000 observations. Estimates when using this sample are provided in column 2 of Table 8 . There are some interesting and notable differences from our base estimates. First, rather than seeing a significant decrease in quantity for the product targeted by the AD action in the market where the AD action takes place, as in the base case, our intensive-margin estimates show no significant change in quantity. This suggests that exit is likely driving the overall quantity decrease for these targeted products, not quantity changes by firmproduct combinations that remain in the market after suffering an $\mathrm{AD}$ action in that market. And this is consistent with the evidence we find on exit that we will discuss next. The other significant change with our intensive margin sample relative to our base case estimates is with respect to the coefficient on AD_OthProd_Mkt; i.e., the change in quantity for the firm's other products in the market where one of its products faces an $\mathrm{AD}$ action. This coefficient is negative and significant for our intensive margin sample, but positive and significant in the base case. The negative coefficient for the intensivemargin sample suggests that the firm reduces quantity for its long-standing products in the market where the AD action takes place, suggesting a chilling effect. The contrasting positive coefficient in the base case can be explained by the firm having substantial growth in any new products they introduce into the market where the AD action takes place, with this effect more than counterbalancing any chilling effect.

We next turn to analyses that examine extensive margin adjustments by the firm in response to $\mathrm{AD}$ actions. In order to evaluate whether $\mathrm{AD}$ actions affect exit probabilities, we start with the sample of firm-product-country (fic) combinations that had non-zero values in the first year of our sample (2000) crossed by each year in the period, 2000 through 2006. This creates a matrix of firm-product-country-year (fict) cells. We then

\footnotetext{
${ }^{25}$ For example, exit could be seen as an infinite increase in price or, at least, an increase to a prohibitive price that we don't observe.
} 
define our dependent variable as a dummy variable that is equal to " 1 " if the fict-cell has positive exports in t-1, but no exports in t (i.e., the exiters), and "0" if it has positive exports in both periods (continuing exporters). We exclude those cells with "zero-zero" values in year period t and period t-1 (continuing non-exporters) or "zero-positive" values (new entrants) in period t-1 and period t. Detailed firm-level data often has instances of the firm making a one-time shipment of product to a market it doesn't typically serve. While our regressions weight observations by export value, to further control for this issue, we include the market share of the product-firm-country observation in the prior period.

Column 3 of Table 8 provides our results. As expected, controlling for the prior market share is important and the significant negative coefficient shows that a higher prior market share means a much lower probability of exit. Interestingly, an AD action has no significant effect on the exit probability for the product in the market where the $\mathrm{AD}$ action takes place, suggesting that firms generally stay and try to mitigate the $\mathrm{AD}$ remedy. However, the AD action has a significant impact on exit probabilities for the other products and markets served by the firm. Consistent with a story of trade deflection, we see that an AD action makes exit less likely for the AD product in other markets, and also less likely for other products sold by the firm across all other markets. We also note that there is no evidence that an AD action leads to increased exit of all the firm's products from the market where the AD action occurs. As discussed in the hypothesis section, if there is a common fixed cost for a firm to export to a particular market, the reduced sales of one of the products could mean the firm can no longer cover the fixed costs and withdraws all of its products from the export market. The evidence suggests the opposite, as exit becomes less likely for the firm's non-targeted products in the market where the $\mathrm{AD}$ action takes place (see coefficient on $A D_{-}$OthProd_Mkt).

Turning to the other extensive margin, we next examine whether AD actions affect entry decisions by multiproduct firms across their products and export markets. For this analysis, we want to consider all the reasonably possible product-market entries that a firm could choose. To do this, we start with all the products we see a firm producing at the beginning of our sample, regardless of where the firm sells them, and then crosses these observed firm-product combinations with all top-50 export markets ${ }^{26}$ where the firm has positive exports at the beginning of the sample. ${ }^{27}$ Our dependent variable for this analysis is a dummy variable equal to " 1 " if the fict-cell has no exports in $t-1$, but positive exports in t (entrants), and " 0 " if it has no exports in both periods (continuing non-exporters).

\footnotetext{
${ }^{26}$ The top 50 export markets are defined by the value of total Chinese exports to these markets at the beginning of the sample.

${ }^{27}$ An alternative strategy would be to consider all possible firm-product combinations, including products the firm has never produced and all possible export destinations. This leads to an extremely large matrix of observations with an overwhelmingly large number of cells taking the value of "0". We prefer our strategy because of the considerable computational cost savings, but also because it focuses on what we consider as the relevant set of possibilities - products currently produced by the firm and export destinations that are receiving more than trivial amounts of Chinese exports.
} 
We exclude firm-product combinations with positive values in both period $t$ and period t-1 (continuing exporters) and those cells where the firm-product-country combination exits.

Column 4 of Table 8 presents results from this analysis of entry probabilities. We find two statistically significant effects related to entry. First, we find that an AD action on a product makes it much less likely to enter that product into other $\mathrm{AD}$ markets. This is largely consistent with a chilling hypothesis, as the firm may be less likely to enter because it perceives the probability of an AD action (should it enter) is now higher as well. The other significant coefficient in the entry regression is a positive one on the regressor, AD_OthProd_OthMkt, suggesting that when a firm faces an AD action on one of its products, entry of its other products into markets other than where the AD action takes place becomes significantly more likely. This is consistent with trade deflection across products within the firm. In contrast, we do not estimate any significant impact on the likelihood of entry by the firm's other products into the market where the AD action takes place. A plausible explanation for this difference is that there is a chilling effect on entry by these other products into the market where the AD action takes place, which counteracts the within-firm trade deflection forces.

\section{Conclusions}

AD actions provide an excellent opportunity to examine how isolated trade actions targeted at only one product and one market affects within-firm production and sales adjustments by multiproduct firms across all its products and export markets. Evidence about such internal adjustments is rare, but critical for understanding various hypotheses about how multiproduct firms make within-firm adjustments. In this paper, we use Chinese micro-level export data during the period of 2000-2006 to explore how AD initiated by foreign countries against China impacts Chinese multiproduct firms' exports. The analyses of these data allow us to uncover a rich array of within-firm adjustments across products and markets, including new phenomena we label within-firm chilling effects of $\mathrm{AD}$ actions and within-firm cross-product trade deflection. We also document substantial heterogeneity in these responses across firm type, countries' use of AD laws, and whether the $\mathrm{AD}$ action targets a firm's core or non-core products. 


\section{References}

Ahn, J., A. Khandelwal and S. Wei, 2011, "The Role of Intermediaries in Facilitating Trade", Journal of International Economics, 84, pp. 73-85.

Arkolakis, C., S. Ganapati and M.-A. Muendler, 2021, "The Extensive Margin of Exporting Products: A Firm-Level Analysis", American Economic Journal: Macroeconomics, 13, pp. $182-245$.

Bailey, E. E., and A. F. Friedlaender, 1982, "Market Structure and Multiproduct Industries", Journal of Economic Literature, 20, pp. 1024-1048.

Bernard, A. B., S. J. Redding and P. K. Schott, 2011, "Multiproduct Firms and Trade Liberalization", The Quarterly Journal of Economics, 126, pp. 1271-1318.

Bernard, A. B., S. J. Redding and P. K. Schott, 2010, "Multiple-Product Firms and Product Switching", American Economic Review, 100, pp. 70-97.

Bliss, C., 1988, "A Theory of Retail Pricing", Journal of Industrial Economics, 36, pp. 375-391.

Blonigen, B. A., 2006, "Working the System: Firm Learning and the Antidumping Process", European Journal of Political Economy, 22, pp. 715-731.

Blonigen, B. A. and J.-H. Park, 2004, "Dynamic Pricing in the Presence of Antidumping Policy: Theory and Evidence", American Economic Review, 94, pp. 134-154.

Bown, C. P., 2011, "Taking Stock of Antidumping, Safeguards and Countervailing Duties, 1990-2009", The World Economy, 34, pp. 1955-1998.

Bown, C. P. and M. A. Crowley, 2006, "Policy Externalities: How US AD Affects Japanese Exports to the EU", European Journal of Political Economy, 22, pp. 696-714.

Bown, C. P. and M.A. Crowley, 2007, "Trade Deflection and Trade Depression", Journal of International Economics, 72, pp. 176-201.

Bown, C. P. and M. A. Crowley, 2010, "China's Export Growth and the China Safeguard: Threats to the World Trading system?" Canadian Journal of Economics, 43, pp. 13531388 .

Brander, J. A. and J. Eaton, 1984, "Product Line Rivalry", American Economic Review, 74, pp. 323-334.

Chandra, P. and C. Long, 2013, "AD Duties and their Impact on Exporters: Firm Level Evidence from China", World Development, 51, pp.169-186.

Demski, J. S., 2008, "Economic Foundations: The Multiproduct Firm", in Managerial Uses of Accounting Information, Boston, MA: Springer, pp. 1-23.

Dhingra, S., 2013, "Trading Away Wide Brands for Cheap Brands," American Economic Review, 103, pp. 2554-2584. 
Eaton, B. C. and N. Schmidt, 1994, "Flexible Manufacturing and Market Structure", American Economic Review, 84, pp. 875-888.

Eckel, C. and P. Neary, 2010, "Multi-Product Firms and Flexible Manufacturing in the Global Economy", Review of Economic Studies, 77, pp. 188-217.

Egger, P. and D. Nelson, 2011, "How Bad Is Antidumping?: Evidence From Panel Data", Review of Economics and Statistics, 93, pp. 1374-1390.

Feenstra, R. C., 1989, "Symmetric Pass-Through of Tariffs and Exchange Rates under Imperfect Competition: An Empirical Test", Journal of International Economics, 27, pp. $25-45$.

Feenstra, R. and H. Ma, 2008, "Optimal Choice of Product Scope For Multiproduct Firms Under Monopolistic Competition", in E. Helpman, D. Marin, and T. Verdier (eds.), The Organization of Firms in a Global Economy, Cambridge, MA: Harvard University Press, pp. 173-99.

Forslid, R. and T. Okubo, 2019, "Trade, Location and Multiproduct Firms," CEPR Discussion Paper No. DP13528.

Goldberg, P., A. K. Khandelwal, N. Pavcnik and P. Topalova, 2010, "Multi-product Firms and Product Turnover in the Developing World: Evidence from India", The Review of Economics and Statistics, 92, pp. 1042-1049.

Iacovone, L. and B. S Javorcik, 2010, "Multi-Product Exporters: "Product Churning, Uncertainty, and Export Discoveries ", The Economic Journal, 120, pp. 481-499.

Jabbour, L., Z. Tao, E. Vanino, and Y. Zhang, 2019, "The Good, the Bad, and the Ugly: Chinese Imports, European Union Anti-dumping Measures and Firm Performance," Journal of International Economics, 117, pp. 1-20.

Johnson, J. P. and D. P. Myatt, 2003, "Multiproduct Quality Competition: Fighting Brands and Product Line Pruning", American Economic Review, 93, pp. 748-774.

Konings, J. and H. Vandenbussche, 2013, "AD Protection Hurts Exporters: Firm-level Evidence", Review of World Economy, 149, pp. 295-320.

Konings, J. and H. Vandenbussche, 2008, "Heterogeneous Responses of Firms to Trade Protection", Journal of International Economics, 76, pp. 371-383.

Konings, J. and H. Vandenbussche, 2005, "AD Protection and Markups of Domestic Firms", Journal of International Economics, 65, pp.151-165.

Krupp, C. M. and P. S. Pollard, 1996, "Market Responses to Antidumping Laws: Some Evidence from the US Chemical Industry", Canadian Journal of Economics, 29, pp. 199-227.

Lu, Y., Z. Tao and Y. Zhang, 2013, "How do Exporters Respond to AD Investigations?", Journal of International Economics, 91, pp. 290-300. 
Manova, K. and Z. Zhang, 2009, "China's Exporters and Importers: Firms, Products and Trade Partners", NBER Working Paper, No.15249.

Mayer, T., M. J. Melitz and G. I. P. Ottaviano, 2014, "Market size, Competition and the Product Mix of Exporters", American Economic Review, 104, pp. 495-536.

Nocke, V. and S. Yeaple, 2014, "Globalization and Multiproduct Firms", International Economic Review, 55, pp. 993-1018.

Ottaviano, G. I. P and J.-F. Thisse, 2011, "Monopolistic Competition, Multiproduct Firms, and Product Diversity", The Manchester School, 79, pp. 938-951.

Pierce, J. R., 2011, "Plant-level Responses to AD Duties: Evidence from U.S. Manufacturers", Journal of International Economics, 85, pp.222-233.

Prusa, T. J., 1997, "The Trade Effects of U.S. AD Actions," in Robert C. Feenstra (ed.), Effects of U.S. Trade Protection and Promotion Policies, University of Chicago Press, pp. 191-214.

Prusa, T. J., 2001, "On the Spread and Impact of AD", Canadian Journal of Economics, 34, pp. 591-611.

Qiu, L. D. and W. Zhou, 2013, "Multiproduct Firms and Scope Adjustment in Globalization," Journal of International Economics, 91, pp. 142-153.

Shaked, A. and J. Sutton, 1990, "Multiproduct Firms and Market Structure", Rand Journal of Economics, 21, pp. 45-62.

Song, H. and L. Zhu, 2010, "Comparative Advantage and Multi-product Firms", Mimeo.

Staiger, R. W. and F. A. Wolak, 1994, "Measuring Industry-Specific Protection: AD in the United States", Brookings Papers: Microeconomics, pp. 51-118.

Tabakis, C. and M. Zanardi, 2017, "Antidumping Echoing", Economic Inquiry, 55, pp. 655681.

Vandenbussche, H. and C. Viegelahn, 2018, "Input Reallocation Within Multi-product Firms", Journal of International Economics, 114, pp. 63-79.

Vandenbussche, H. and M. Zanardi, 2010, "The Chilling Trade Effects of Antidumping Proliferation", European Economic Review, 54, pp. 760-777. 


\begin{tabular}{|c|c|c|c|c|}
\hline \multicolumn{5}{|l|}{ A. Effects for Targeted Product } \\
\hline \multirow{5}{*}{$\begin{array}{l}\text { Constant Marginal Costs } \\
\text { Increasing Marginal Costs } \\
\text { Chilling Effect }\end{array}$} & \multicolumn{2}{|c|}{ Country with AD Action } & \multicolumn{2}{|c|}{ Other Countries } \\
\hline & Price & Quantity & Price & Quantity \\
\hline & + & - & 0 & 0 \\
\hline & + & - & - & + \\
\hline & + & - & + & - \\
\hline \multicolumn{5}{|l|}{ B. Effects for Firm's Other Products } \\
\hline \multirow{4}{*}{$\begin{array}{l}\text { Constant Marginal Costs / No Demand Relationships } \\
\text { Increasing Marginal Costs / No Demand Relationships }\end{array}$} & \multicolumn{2}{|c|}{ Country with AD Action } & \multicolumn{2}{|c|}{ Other Countries } \\
\hline & Price & Quantity & Price & Quantity \\
\hline & 0 & 0 & 0 & 0 \\
\hline & - & + & - & + \\
\hline Substitute Goods & + & + & 0 & 0 \\
\hline Substitute Goods with Trade Deflection & + & + & - & - \\
\hline Chilling Effect & + & - & + & - \\
\hline
\end{tabular}


Table 2. Summary Statistics of the Chinese Export Data

\begin{tabular}{|c|c|c|c|c|c|c|c|}
\hline Year & 2000 & 2001 & 2002 & 2003 & 2004 & 2005 & $\overline{2006}$ \\
\hline \multicolumn{8}{|l|}{ A. All Firms vs. MP Firms } \\
\hline No. of All Firms & 62,536 & 68,291 & 75,276 & 90,587 & 109,856 & 116,320 & 158,928 \\
\hline No. of MP Firms & 44,931 & 49,387 & 55,729 & 67,855 & 83,354 & 89,124 & 124,278 \\
\hline Share of MP Firms & 0.718 & 0.723 & 0.740 & 0.749 & 0.759 & 0.766 & 0.782 \\
\hline Exports by All Firms* & 248 & 290 & 299 & 436 & 586 & 718 & 958 \\
\hline Exports by MP Firms* & 230 & 269 & 279 & 407 & 548 & 675 & 901 \\
\hline Share of Exports by MP Firms & 0.927 & 0.928 & 0.933 & 0.933 & 0.935 & 0.940 & 0.941 \\
\hline \multicolumn{8}{|c|}{ "B. MP Firms: Destination Countries and Products } \\
\hline Avg No. of Countries per Firm & 7 & 8 & 8 & 8 & 8 & 8 & 8 \\
\hline Avg No. of Products per Firm & 19 & 19 & 19 & 20 & 20 & 19 & 21 \\
\hline Avg No. of Country-product Pairs per Firm & 36 & 37 & 38 & 41 & 40 & 40 & 41 \\
\hline \multicolumn{8}{|l|}{ C. MP Firms: Mfg Firms and Non-SOEs } \\
\hline Share of Mfg Firms: No. of Firms & 0.851 & 0.849 & 0.849 & 0.836 & 0.805 & 0.805 & 0.736 \\
\hline Share of Mfg Firms: Export Value & 0.646 & 0.672 & 0.702 & 0.731 & 0.756 & 0.779 & 0.776 \\
\hline Share of Non-SOEs: No. of Firms & 0.810 & 0.798 & 0.807 & 0.845 & 0.884 & 0.902 & 0.932 \\
\hline Share of Non-SOEs: Export Value & 0.539 & 0.558 & 0.608 & 0.675 & 0.730 & 0.763 & 0.796 \\
\hline Share of Mfg Non-SOEs: No. of Firms & 0.762 & 0.752 & 0.754 & 0.758 & 0.745 & 0.754 & 0.698 \\
\hline Share of Mfg Non-SOEs: Export Value & 0.506 & 0.529 & 0.571 & 0.613 & 0.649 & 0.678 & 0.682 \\
\hline
\end{tabular}

* in billion dollars. 
Table 3. AD Initiation Cases Against China

\begin{tabular}{|c|c|c|c|c|c|c|c|c|c|}
\hline A. AD Initiation Cases & 1999 & 2000 & 2001 & 2002 & 2003 & 2004 & 2005 & 2006 & $\overline{\overline{\text { Total }}}$ \\
\hline Argentina & 3 & 2 & 9 & 2 & & 2 & 3 & 1 & 22 \\
\hline Australia & 1 & 2 & 4 & 1 & 2 & 2 & 2 & 3 & 17 \\
\hline Brazil & & & 3 & 1 & 2 & 1 & & 11 & 18 \\
\hline Colombia & & & & & & 2 & 1 & 11 & 14 \\
\hline European Union & 12 & 6 & 1 & 4 & 3 & 9 & 8 & 12 & 55 \\
\hline India & 6 & 10 & 12 & 14 & 6 & 7 & 10 & 8 & 73 \\
\hline Indonesia & 1 & & & 1 & 1 & 1 & & 1 & 5 \\
\hline Israel & & & & & & 1 & 2 & & 3 \\
\hline Jamaica & & & & & 1 & & & & 1 \\
\hline Mexico & 1 & & 2 & 2 & 3 & 1 & 5 & 3 & 17 \\
\hline New Zealand & 1 & & & & 1 & 1 & & 1 & 4 \\
\hline Pakistan & & & & & & & 1 & 1 & 2 \\
\hline Peru & 4 & & 3 & 1 & 2 & 2 & 1 & 1 & 14 \\
\hline Philippines & & 1 & & & & & & & 1 \\
\hline South Africa & 2 & 3 & & & 4 & 1 & 5 & 1 & 16 \\
\hline South Korea & 1 & & & 1 & 2 & 1 & 2 & 1 & 8 \\
\hline Taiwan & & & & & & & & 3 & 3 \\
\hline Trinidad and Tobago & 1 & & & & 1 & & & & 2 \\
\hline Turkey & 1 & 2 & 4 & 7 & 15 & 12 & 4 & 5 & 50 \\
\hline USA & 7 & 7 & 8 & 9 & 10 & 6 & 4 & 4 & 55 \\
\hline Total Number of Cases & 41 & 33 & 46 & 43 & 53 & 49 & 48 & 67 & 380 \\
\hline Cases with Final AD Measures & 24 & 26 & 35 & 36 & 44 & 42 & 36 & 48 & 291 \\
\hline Share of Cases with Final AD Measures & 0.59 & 0.79 & 0.76 & 0.84 & 0.83 & 0.86 & 0.75 & 0.72 & 0.77 \\
\hline \multicolumn{10}{|l|}{ B. Exports Impacted by AD Cases } \\
\hline No. of Country-product Pairs Targeted & & 72 & 78 & 81 & 60 & 103 & 99 & 135 & \\
\hline Total No. of Country-product Pairs & & 161,199 & 173,377 & 183,003 & 206,617 & 210,628 & 224,271 & 250,422 & \\
\hline Share of Country-product Pairs Targeted & & 0.00045 & 0.00045 & 0.00044 & 0.00029 & 0.00049 & 0.00044 & 0.00054 & \\
\hline Export Value Targeted* & & 0.80 & 1.17 & 2.07 & 2.77 & 1.94 & 4.00 & 4.12 & \\
\hline Total Export Value* & & 248 & 290 & 299 & 436 & 586 & 718 & 958 & \\
\hline Share of Export Value Targeted & & 0.00323 & 0.00403 & 0.00692 & 0.00635 & 0.00331 & 0.00557 & 0.00430 & \\
\hline
\end{tabular}


Table 4. Price and Quantity Responses to AD Actions for the Full Sample

\begin{tabular}{c|cc}
\hline \hline & Price & Quantity \\
\cline { 2 - 3 } & 1 & 2 \\
\hline \multirow{3}{*}{ AD_Prod_Mkt } & $0.0389 * * *$ & $-0.0529 * * *$ \\
AD_Prod_OthMkt & {$[0.00239]$} & {$[0.00510]$} \\
& $0.0203^{* * *}$ & $-0.0530^{* * *}$ \\
AD_OthProd_Mkt & {$[0.00147]$} & {$[0.00314]$} \\
& $-0.0273^{* * *}$ & $0.0125^{* * *}$ \\
AD_OthProd_OthMkt & {$[0.00101]$} & {$[0.00215]$} \\
& $-0.0372^{* * *}$ & $0.0466^{* * *}$ \\
& {$[0.000721]$} & {$[0.00154]$} \\
\hline No. of Observations & $4,395,027$ & $4,395,027$ \\
R & 0.486 & 0.266 \\
\hline \hline
\end{tabular}

Notes: All regressions include firm-product-country (fic) fixed effects and country-time (ct) fixed effects and observations are weighted by export value. 
Table 5. Difference in Price and Quantity Responses Across Different Firm Types

\begin{tabular}{|c|c|c|c|c|c|c|}
\hline & \multicolumn{2}{|c|}{ Base Case } & \multicolumn{2}{|c|}{$\begin{array}{c}\text { State-owned Enterprise } \\
\text { (SOEs) }\end{array}$} & \multicolumn{2}{|c|}{ Non-SOEs } \\
\hline & Price & Quantity & Price & Quantity & Price & Quantity \\
\hline & 1 & 2 & 3 & 4 & 5 & 6 \\
\hline$A D \_P r o d \_M k t$ & $\begin{array}{c}0.0389 * * * \\
{[0.00239]}\end{array}$ & $\begin{array}{c}-0.0529 * * * \\
{[0.00510]}\end{array}$ & $\begin{array}{l}0.0173 * * * \\
{[0.00349]}\end{array}$ & $\begin{array}{c}-0.0740 * * * \\
{[0.00754]}\end{array}$ & $\begin{array}{c}0.0469 * * * \\
{[0.00323]}\end{array}$ & $\begin{array}{c}-0.0415 * * * \\
{[0.00688]}\end{array}$ \\
\hline AD_Prod_OthMkt & $\begin{array}{l}0.0203 * * * \\
{[0.00147]}\end{array}$ & $\begin{array}{c}-0.0530 * * * \\
{[0.00314]}\end{array}$ & $\begin{array}{c}0.00861 * * * \\
{[0.00202]}\end{array}$ & $\begin{array}{c}-0.0195 * * * \\
{[0.00436]}\end{array}$ & $\begin{array}{c}0.0248 * * * \\
{[0.00205]}\end{array}$ & $\begin{array}{c}-0.0575 * * * \\
{[0.00437]}\end{array}$ \\
\hline$A D \_O t h P r o d \_M k t$ & $\begin{array}{c}-0.0273 * * * \\
{[0.00101]}\end{array}$ & $\begin{array}{l}0.0125 * * * \\
{[0.00215]}\end{array}$ & $\begin{array}{c}-0.0201 * * * \\
{[0.00151]}\end{array}$ & $\begin{array}{l}-0.00325 \\
{[0.00326]}\end{array}$ & $\begin{array}{c}-0.0354 * * * \\
{[0.00136]}\end{array}$ & $\begin{array}{l}0.0281 * * * \\
{[0.00290]}\end{array}$ \\
\hline AD_OthProd_OthMkt & $\begin{array}{l}-0.0372 * * * \\
{[0.000721]}\end{array}$ & $\begin{array}{l}0.0466^{* * * *} \\
{[0.00154]}\end{array}$ & $\begin{array}{c}-0.00631 * * * \\
{[0.00103]}\end{array}$ & $\begin{array}{c}0.00583 * * * \\
{[0.00223]}\end{array}$ & $\begin{array}{l}-0.0530 * * * \\
{[0.000997]}\end{array}$ & $\begin{array}{l}0.0680 * * * \\
{[0.00213]}\end{array}$ \\
\hline \multirow[t]{4}{*}{$\begin{array}{l}\text { No. of Observations } \\
\mathrm{R}^{2} \\
\end{array}$} & $\begin{array}{c}4,395,027 \\
0.486 \\
\end{array}$ & $\begin{array}{c}, 395,027 \\
0.266 \\
\end{array}$ & $\begin{array}{c}1,954,280 \\
0.525 \\
\end{array}$ & $\begin{array}{c}1,954,280 \\
0.26\end{array}$ & $\begin{array}{c}2,440,647 \\
0.477 \\
\end{array}$ & $\begin{array}{c}2,440,647 \\
0.276\end{array}$ \\
\hline & \multicolumn{2}{|c|}{ Trade Intermediaries } & \multicolumn{2}{|c|}{ Manufacturing Firms } & \multicolumn{2}{|c|}{$\begin{array}{c}\text { Non-SOE, Manufacturing } \\
\text { Firms }\end{array}$} \\
\hline & Price & Quantity & Price & Quantity & Price & Quantity \\
\hline & 7 & 8 & 9 & 10 & 11 & 12 \\
\hline$A D \_P r o d \_M k t$ & $\begin{array}{c}0.0160 * * * \\
{[0.00331]}\end{array}$ & $\begin{array}{c}-0.0199 * * * \\
{[0.00742]}\end{array}$ & $\begin{array}{l}0.0439 * * * \\
{[0.00326]}\end{array}$ & $\begin{array}{c}-0.0570 * * * \\
{[0.00687]}\end{array}$ & $\begin{array}{c}0.0432 * * * \\
{[0.00369]}\end{array}$ & $\begin{array}{c}-0.0305^{* * * *} \\
{[0.00778]}\end{array}$ \\
\hline AD_Prod_OthMkt & $\begin{array}{c}-0.00532 * * * \\
{[0.00195]}\end{array}$ & $\begin{array}{c}-0.00484 \\
{[0.00436]}\end{array}$ & $\begin{array}{l}0.0274 * * * \\
{[0.00204]}\end{array}$ & $\begin{array}{c}-0.0609 * * * \\
{[0.00429]}\end{array}$ & $\begin{array}{c}0.0199 * * * \\
{[0.00239]}\end{array}$ & $\begin{array}{c}-0.0588 * * * \\
{[0.00504]}\end{array}$ \\
\hline$A D \_O t h P r o d \_M k t$ & $\begin{array}{c}-0.00765^{* * *} \\
{[0.00140]}\end{array}$ & $\begin{array}{l}0.0225^{* * * *} \\
{[0.00315]}\end{array}$ & $\begin{array}{c}-0.0395 * * * \\
{[0.00138]}\end{array}$ & $\begin{array}{l}0.0295 * * * \\
{[0.00291]}\end{array}$ & $\begin{array}{c}-0.0413 * * * \\
{[0.00156]}\end{array}$ & $\begin{array}{l}0.0426^{* * *} \\
{[0.00328]}\end{array}$ \\
\hline AD_OthProd_OthMkt & $\begin{array}{c}-0.00527 * * * \\
{[0.000963]}\end{array}$ & $\begin{array}{c}0.00914 * * * \\
{[0.00216]}\end{array}$ & $\begin{array}{l}-0.0550 * * * \\
{[0.00101]}\end{array}$ & $\begin{array}{l}0.0763 * * * \\
{[0.00212]}\end{array}$ & $\begin{array}{c}-0.0605^{* * *} \\
{[0.00115]}\end{array}$ & $\begin{array}{l}0.0841 * * * \\
{[0.00242]}\end{array}$ \\
\hline No. of Observations & $1,925,387$ & $1,925,387$ & $2,463,335$ & $2,463,335$ & $1,897,060$ & $1,897,060$ \\
\hline$\underline{R}^{2}$ & 0.515 & 0.263 & 0.483 & 0.275 & 0.472 & 0.472 \\
\hline
\end{tabular}

Notes: All regressions include firm-product-country (fic) fixed effects and country-time (ct) fixed effects and observations are weighted by export value. 
Table 6. Difference in Price and Quantity Responses Across Different Types of AD Measures and Presence of AD Laws in Countries

\begin{tabular}{|c|c|c|c|c|c|c|c|c|c|c|}
\hline & \multicolumn{2}{|c|}{ Base Case } & \multicolumn{2}{|c|}{$\begin{array}{c}\text { Affirmative AD Cases } \\
\text { Only }\end{array}$} & \multicolumn{2}{|c|}{$\begin{array}{c}\text { Affirmative Cases } \\
\text { Excluding Those With } \\
\text { AD Duties }>50 \%\end{array}$} & \multicolumn{2}{|c|}{ Countries with AD Laws } & \multicolumn{2}{|c|}{$\begin{array}{c}\text { Countries Without AD } \\
\text { Laws }\end{array}$} \\
\hline & Price & Quantity & Price & Quantity & Price & Quantity & Price & Quantity & Price & Quantity \\
\hline & 1 & 2 & 3 & 4 & 5 & 6 & 7 & 8 & 9 & 10 \\
\hline$A D \_P r o d \_M k t$ & $\begin{array}{c}0.0432 * * * \\
{[0.00369]}\end{array}$ & $\begin{array}{c}-0.0305 * * * \\
{[0.00778]}\end{array}$ & $\begin{array}{c}0.0398 * * * \\
{[0.00432]}\end{array}$ & $\begin{array}{c}-0.015 \\
{[0.00911]}\end{array}$ & $\begin{array}{c}0.0815 * * * \\
{[0.00828]}\end{array}$ & $\begin{array}{c}-0.227 * * * \\
{[0.0173]}\end{array}$ & $\begin{array}{c}0.0429 * * * \\
{[0.00365]}\end{array}$ & $\begin{array}{c}-0.0310 * * * \\
{[0.00785]}\end{array}$ & & \\
\hline AD_Prod_OthMkt & $\begin{array}{c}0.0199 * * * \\
{[0.00239]}\end{array}$ & $\begin{array}{c}-0.0588 * * * \\
{[0.00504]}\end{array}$ & $\begin{array}{l}0.00587 * \\
{[0.00322]}\end{array}$ & $\begin{array}{l}-0.0146 * * \\
{[0.00678]}\end{array}$ & $\begin{array}{c}0.0397 * * * \\
{[0.00420]}\end{array}$ & $\begin{array}{c}-0.0472 * * * \\
{[0.00878]}\end{array}$ & $\begin{array}{l}0.0300 * * * \\
{[0.00257]}\end{array}$ & $\begin{array}{c}-0.0340 * * * \\
{[0.00553]}\end{array}$ & $\begin{array}{c}-0.0344 * * * \\
{[0.00629]}\end{array}$ & $\begin{array}{c}-0.192 * * * \\
{[0.0125]}\end{array}$ \\
\hline$A D \_O t h P r o d \_M k t$ & $\begin{array}{c}-0.0413 * * * \\
{[0.00156]}\end{array}$ & $\begin{array}{c}0.0426 * * * \\
{[0.00328]}\end{array}$ & $\begin{array}{c}-0.0413 * * * \\
{[0.00161]}\end{array}$ & $\begin{array}{c}0.0530 * * * \\
{[0.00338]}\end{array}$ & $\begin{array}{c}-0.0615 * * * \\
{[0.00251]}\end{array}$ & $\begin{array}{c}0.0491 * * * \\
{[0.00524]}\end{array}$ & $\begin{array}{c}-0.0406 * * * \\
{[0.00154]}\end{array}$ & $\begin{array}{c}0.0447 * * * \\
{[0.00331]}\end{array}$ & & \\
\hline AD_OthProd_OthMkt & $\begin{array}{c}-0.0605 * * * \\
{[0.00115]}\end{array}$ & $\begin{array}{c}0.0841 * * * \\
{[0.00242]}\end{array}$ & $\begin{array}{c}-0.0717 * * * \\
{[0.00120]}\end{array}$ & $\begin{array}{l}0.0861 * * * \\
{[0.00254]}\end{array}$ & $\begin{array}{c}-0.0955 * * * \\
{[0.00180]}\end{array}$ & $\begin{array}{c}0.0479 * * * \\
{[0.00377]}\end{array}$ & $\begin{array}{c}-0.0669 * * * \\
{[0.00128]}\end{array}$ & $\begin{array}{c}0.0606 * * * \\
{[0.00275]}\end{array}$ & $\begin{array}{c}-0.0357 * * * \\
{[0.00260]}\end{array}$ & $\begin{array}{l}0.174 * * * \\
{[0.00515]}\end{array}$ \\
\hline No. of Observations & $1,897,060$ & $1,897,060$ & $1,897,063$ & $1,897,063$ & $1,691,920$ & $1,691,920$ & $1,417,263$ & $1,417,263$ & 479,797 & 479,797 \\
\hline $\mathrm{R}^{2}$ & 0.472 & 0.279 & 0.472 & 0.279 & .476 & 0.291 & 0.477 & 0.27 & 0.456 & 0.307 \\
\hline
\end{tabular}

Notes: All regressions include firm-product-country (fic) fixed effects and country-time (ct) fixed effects and observations are weighted by export value. The base sample in columns 1 and 2 consists of all firm-product-country-year observations connected to non-SOE, manufacturing firms. 
Table 7. Difference in Price and Quantity Responses Across Core and Non-core Products

\begin{tabular}{|c|c|c|c|c|c|c|c|c|c|c|}
\hline & \multicolumn{2}{|c|}{ Base Case } & \multicolumn{2}{|c|}{$\begin{array}{c}\text { Case A: Non-core sample; } \\
\text { Non-core AD actions }\end{array}$} & \multicolumn{2}{|c|}{$\begin{array}{l}\text { Case B: Core sample; } \\
\text { Core AD actions }\end{array}$} & \multicolumn{2}{|c|}{$\begin{array}{c}\text { Case C: Non-core sample; } \\
\text { Core AD actions }\end{array}$} & \multicolumn{2}{|c|}{$\begin{array}{l}\text { Case D: Core sample; } \\
\text { Non-core AD actions }\end{array}$} \\
\hline & Price & Quantity & Price & Quantity & Price & Quantity & Price & Quantity & Price & Quantity \\
\hline & 1 & 2 & 3 & 4 & 5 & 6 & 7 & 8 & 9 & 10 \\
\hline$A D \_P r o d \_M k t$ & $\begin{array}{c}0.0432 * * * \\
{[0.00369]}\end{array}$ & $\begin{array}{c}-0.0305 * * * \\
{[0.00778]}\end{array}$ & $\begin{array}{c}0.0128 * * * \\
{[0.00441]}\end{array}$ & $\begin{array}{c}0.000277 \\
{[0.00915]}\end{array}$ & $\begin{array}{c}0.0704 * * * \\
{[0.00712]}\end{array}$ & $\begin{array}{c}-0.0536 * * * \\
{[0.0155]}\end{array}$ & & & & \\
\hline AD_Prod_OthMkt & $\begin{array}{c}0.0199 * * * \\
{[0.00239]}\end{array}$ & $\begin{array}{c}-0.0588 * * * \\
{[0.00504]}\end{array}$ & $\begin{array}{c}0.0426 * * * \\
{[0.00307]}\end{array}$ & $\begin{array}{c}-0.0685 * * * \\
{[0.00636]}\end{array}$ & $\begin{array}{c}-0.0130 * * * \\
{[0.00425]}\end{array}$ & $\begin{array}{c}-0.0283 * * * \\
{[0.00922]}\end{array}$ & & & & \\
\hline$A D \_O t h P r o d \_M k t$ & $\begin{array}{c}-0.0413 * * * \\
{[0.00156]}\end{array}$ & $\begin{array}{c}0.0426 * * * \\
{[0.00328]}\end{array}$ & $\begin{array}{c}-0.0679 * * * \\
{[0.00181]}\end{array}$ & $\begin{array}{c}0.0522 * * * \\
{[0.00375]}\end{array}$ & & & $\begin{array}{l}0.0708 * * * \\
{[0.00717]}\end{array}$ & $\begin{array}{l}-0.0125 \\
{[0.0148]}\end{array}$ & $\begin{array}{c}0.00126 \\
{[0.00318]}\end{array}$ & $\begin{array}{c}0.0135^{*} \\
{[0.00691]}\end{array}$ \\
\hline AD_OthProd_OthMkt & $\begin{array}{c}-0.0605 * * * \\
{[0.00115]}\end{array}$ & $\begin{array}{c}0.0841 * * * \\
{[0.00242]}\end{array}$ & $\begin{array}{c}-0.0849 * * * \\
{[0.00131]}\end{array}$ & $\begin{array}{l}0.115 * * * \\
{[0.00271]}\end{array}$ & & & $\begin{array}{l}0.0727 * * * \\
{[0.00476]}\end{array}$ & $\begin{array}{c}-0.0903 * * * \\
{[0.00985]}\end{array}$ & $\begin{array}{c}-0.0243 * * * \\
{[0.00251]}\end{array}$ & $\begin{array}{c}0.00786 \\
{[0.00545]}\end{array}$ \\
\hline $\begin{array}{l}\text { Sample } \\
\text { AD definitions }\end{array}$ & $\begin{array}{l}\text { All } \\
\text { All } \\
\end{array}$ & $\begin{array}{l}\text { All } \\
\text { All } \\
\end{array}$ & $\begin{array}{l}\text { Non-core } \\
\text { Non-core }\end{array}$ & $\begin{array}{l}\text { Non-Core } \\
\text { Non-core }\end{array}$ & $\begin{array}{l}\text { Core } \\
\text { Core }\end{array}$ & $\begin{array}{l}\text { Core } \\
\text { Core }\end{array}$ & $\begin{array}{c}\text { Non-core } \\
\text { Core } \\
\end{array}$ & $\begin{array}{c}\text { Non-core } \\
\text { Core }\end{array}$ & $\begin{array}{c}\text { Core } \\
\text { Non-core } \\
\end{array}$ & $\begin{array}{c}\text { Core } \\
\text { Non-core } \\
\end{array}$ \\
\hline $\begin{array}{l}\text { No. of Observations } \\
\mathrm{R}^{2}\end{array}$ & $\begin{array}{c}1,897,060 \\
0.472 \\
\end{array}$ & $\begin{array}{c}1,897,060 \\
0.279 \\
\end{array}$ & $\begin{array}{c}1,517,776 \\
0.499 \\
\end{array}$ & $\begin{array}{c}1,517,776 \\
0.275 \\
\end{array}$ & $\begin{array}{c}379,149 \\
0.419 \\
\end{array}$ & $\begin{array}{c}379,149 \\
0.287 \\
\end{array}$ & $\begin{array}{c}1,517,776 \\
0.496 \\
\end{array}$ & $\begin{array}{c}1,517,776 \\
0.274 \\
\end{array}$ & $\begin{array}{c}379,149 \\
0.419 \\
\end{array}$ & $\begin{array}{c}379,149 \\
0.287 \\
\end{array}$ \\
\hline
\end{tabular}

Notes: All regressions include firm-product-country (fic) fixed effects and country-time (ct) fixed effects and observations are weighted by export value. The base sample in columns 1 and 2 consists of all firm-product-country-year observations connected to non-SOE, manufacturing firms. 
Table 8. Intensive and Extensive Margins

\begin{tabular}{|c|c|c|c|c|}
\hline & $\begin{array}{c}\text { Base - Non-SOE, } \\
\text { Manufacturing Firms }\end{array}$ & $\begin{array}{l}\text { Intensive (firm-product- } \\
\text { country cells in all years) }\end{array}$ & Exit & Entry \\
\hline & Quantity & Quantity & Dummy & Dummy \\
\hline & 1 & 2 & 3 & 4 \\
\hline$A D \_P r o d \_M k t$ & $\begin{array}{c}-0.0305 * * * \\
{[0.00778]}\end{array}$ & $\begin{array}{c}-0.017 \\
{[0.0149]}\end{array}$ & $\begin{array}{c}0.00777 \\
{[0.00794]}\end{array}$ & $\begin{array}{c}-0.000216 \\
{[0.000439]}\end{array}$ \\
\hline AD_Prod_OthMkt & $\begin{array}{c}-0.0588 * * * \\
{[0.00504]}\end{array}$ & $\begin{array}{c}-0.0458 * * * \\
{[0.00961]}\end{array}$ & $\begin{array}{c}-0.00984 * * * \\
{[0.00259]}\end{array}$ & $\begin{array}{c}-0.000323 * * * \\
{[0.000098]}\end{array}$ \\
\hline \multirow{2}{*}{ AD_OthProd_Mkt } & $0.0426 * * *$ & $-0.0256 * * *$ & $-0.00967 * * *$ & -0.000066 \\
\hline & $\begin{array}{l}{[0.00328]} \\
00841 * * *\end{array}$ & $\begin{array}{l}{[0.00670]} \\
00404 * * *\end{array}$ & {$[0.00307]$} & $\begin{array}{l}{[0.000099]} \\
0\end{array}$ \\
\hline AD_OthProd_OthMkt & {$[0.00242]$} & {$[0.00495]$} & {$[0.00202]$} & {$[0.000054]$} \\
\hline \multirow[t]{2}{*}{ Prior Market Share } & & & $-0.286 * * *$ & \\
\hline & & & {$[0.00406]$} & \\
\hline No. of Observations & $1,897,060$ & 338,740 & 905,919 & $32,903,837$ \\
\hline$\underline{\mathrm{R}}^{2}$ & 0.279 & 0.267 & 0.452 & 0.376 \\
\hline
\end{tabular}

"Exit" is a dummy that is equal to 1 if the fict-cell has positive exports in $\mathrm{t}-1$ but no exports in $\mathrm{t}$ (exiters), and 0 if it has positive exports in both periods

(continuing exporters). The Eixt regression sample consists of the balanced panel with all fic cells that has positive exports in year 2000 crossed by each year in the period 2000-2006, but EXCLUDING those with "zero-zero" (continuing non-exporters) or "zero-positive" (new entrants) exports in period t-1 and period t.

(3) "Entry" is a dummy that is equal to 1 if the fict-cell has no exports in $\mathrm{t}-1$ but positive exports in $\mathrm{t}$ (entrants), and 0 if it has no exports in both periods

(continuing non-exporters). The Entry regression sample consists of the balanced panel with all fi pairs that has positive exports in year 2000 crossed by all

Chinese top 50 export destination countries that the firm $\mathrm{f}$ has positive exports in 2000, and then by each year in the period 2000-2006, but EXCLUDING those

with "positive-positive" (continuing exporters) or "positive-zero" (exiters) exports in period t-1 and period t. 